\title{
IMPARCIALIDAD DEL TRIBUNAL ORAL EN LO PENAL: TRAS LA CONQUISTA DE LA GARANTÍA*
}

\author{
Germán Echeverría Ramírez**
}

\begin{abstract}
RESUMEN
Controlar la indiferencia judicial, las amenazas de prejuicio del juzgador y garantizar a los acusados niveles adecuados de confianza en la neutralidad del juez, constituyen los aspectos del juicio oral que mayores dificultades plantean al litigante. No sólo en cuanto al contenido y alcance de la garantía de imparcialidad del tribunal asegurada en el primer artículo del Código Procesal Penal, sino también respecto del procedimiento y oportunidad de alegar su transgresión. A quí se esboza una dimensión subjetiva de la misma, pero también de protección de las apariencias de neutralidad; se analizan algunos incidentes surgidos de la práctica forense y se distinguen los procedimientos de cautela de esta garantía de aquellos reparatorios o represivos de su infracción, evitando así una confusión conceptual que a menudo ba creado desinteligencias argumentativas y decisiones insatisfactorias.
\end{abstract}

INDEPENDENCIA JUDICIAL - IMPARCIALIDAD - JURISDICCIÓN

Impartiality of the oral court in crime: In quest for guarantee

\begin{abstract}
Controlling judicial indifference or the judge's prejudice threat and guaranteeing adequate trust levels for defendants in the judge's neutrality, are one of the oral procedure's aspects that cause most difficulties for litigators. Not only with regard to the content and the reach of the court's guaranteed impartiality, insured in the Criminal Code, but also with regard to the procedure and the opportunity to plead its transgression. In this work a subjective dimension of impartiality is outlined, and also the need of protection of neutral appearances; some incidents in forensic practices are analyzed, and preventive procedures in favor of impartiality are distinguished from those directed to the redress or the repression of its infraction, avoiding conceptual confusions that have often created argumentative errors and unsatisfactory decisions.
\end{abstract}

\section{JUDICIAL INDEPENDENCE - IMPARTIALITY - JURISDICTION}

* Esta publicación surge del trabajo de asesoría jurídica proporcionada por la Unidad de Estudios de la Defensoría Regional de Los Lagos a los prestadores de defensa penal pública de este territorio.

Mis agradecimientos para los abogados de la Unidad de Estudios de la Defensoría Nacional, Claudia Castelletti Font y Juan Manuel Fernández Ruiz, como también para el entonces Jefe de Estudios de la Defensoría Regional de Los Lagos y actual Director Nacional de Gendarmería de Chile, Luis Masferrer Farías, como también para el Jefe de Estudios de la Defensoría Regional del Bío-Bío, Pelayo Vial Campos, por sus documentadas observaciones y comentarios que otorgaron mayor claridad y profundidad al texto. También quiero agradecer al Centro de Documentación de la Defensoría Nacional y al defensor penal público Cristian Rozas Dockendorff, por la útil y valiosa información que me proporcionaron durante la gestación de este artículo.

** Abogado y Periodista. Profesional de la Unidad de Estudios de la Defensoría Regional de Los Lagos, Chile, gecheverria@dpp.cl

Artículo recibido el 2 de diciembre de 2009 y aceptado para su publicación por el Comité Editorial el 28 de mayo de 2010. 
U na de las paradojas más estruendosas de la actual justicia criminal es la centralidad y primacía que el legislador reconoció a la garantía del juez imparcial ${ }^{1-2}$ en nuestro joven proceso penal y la indisimulada resistencia e incomodidad ${ }^{3}$ que, sin embargo, hoy despierta su reclamo como acto de postulación procesal ${ }^{4}$.

En este escenario de debates orales y públicos, el tono muchas veces destemplado de su discusión asoma nítido, no sólo en las alegaciones y desapacibles decisiones sobre la materia ${ }^{5}$, sino, más elocuente aun, en el rictus de quienes expresan y soportan los reclamos ${ }^{6}$. Como si de acuerdo a los códigos de nuestra cultura local fuera no sólo una felonía, sino una suerte de ofensa escrutar públicamente en audiencia las sombras de parcialidad del juzgador.

Este debate sobre la indiferencia judicial frente a las peticiones de las partes puede ser percibido como una especie de invectiva contra la alta investidura de los magistrados. Especialmente entre quienes adhieren a un proceso esencialmente inquisitivo y

${ }^{1}$ Artículo 1 del Código Procesal Penal. Juicio previo y única persecución. Ninguna persona podrá ser condenada o penada, ni sometida a una de las medidas de seguridad establecidas en este Código, sino en virtud de una sentencia fundada, dictada por un tribunal imparcial.

${ }^{2}$ El Manual de Derecho Internacional de los Derechos Humanos para Defensores Penales Públicos de Chile de diciembre de 2003 sostiene que la idea de imparcialidad contenida en el artículo 1 del Código Procesal Penal debe entenderse de la manera en que se ha desarrollado en el Derecho Internacional, vale decir, deberá ser una imparcialidad tanto objetiva como subjetiva.

${ }^{3}$ En la causa Rol 173-07 de la Iltma. Corte de Apelaciones de Copiapó se deja constancia en su considerando tercero que a las objeciones de la defensa frente a la actitud parcial de la Juez Presidente del Tribunal Oral en lo Penal que decide interrogar en forma autónoma a un testigo de cargo, la propia magistrado se encarga de aclarar al abogado que las preguntas formuladas por los miembros del tribunal no pueden ser materia de objeción por los intervinientes, agregando que aquello se lo señala de plano a la defensa...

${ }^{4}$ Colombo Campbell, Juan, Los Actos Procesales, Tomo II, Editorial Jurídica de Chile, Santiago, 1997, ps. 354 y ss. El autor sostiene que los actos procesales pueden clasificarse atendiendo a distintos puntos de vista, entre los que pueden distinguirse los actos de obtención o de postulación destinados a obtener una resolución judicial, actos de prueba tendientes a demostrar los hechos invocados y actos de causación o constitutivos, generadores de situaciones procesales.

Los denominados actos de postulación procesal son, por su naturaleza, los clásicos actos procesales de las partes, que integran el núcleo central del proceso. Se definen como aquellos que tienen por fin conseguir una resolución judicial de determinado contenido mediante influjos psíquicos ejercidos sobre el juez. El destinatario de los actos de postulación es siempre el juez.

${ }^{5}$ La edición aparecida el miércoles 18 de abril de 2007 del diario El Llanquibue de Puerto Montt publica una nota titulada "Juez versus Defensor", donde informa que el defensor de uno de los acusados en el llamado caso Piccardo objetó una de las preguntas del Juez Presidente de la sala, precisamente para cautelar la imparcialidad del Tribunal, lo que según el artículo de prensa provocó molestia en el juez, quien a la actuación del defensor replicó: ¿Acaso quiere responder usted la pregunta, señor Defensor?

${ }^{6}$ En la causa Rol Ingreso No 86-2008 de la Iltma. Corte de Apelaciones de Puerto Montt, el Ministerio Público cuestionó en duros términos la actuación profesional del defensor de un acusado menor de edad, quien reclamó la nulidad de una actuación judicial realizada fuera de audiencia y en cuya virtud los juzgadores trajeron a la vista la copia de la carpeta de investigación fiscal sin conocimiento de la defensa, por estimar que de ese modo se habían infringido las garantías que aseguraban al justiciable su derecho a un tribunal imparcial y la posibilidad de intervenir en todas las actuaciones judiciales del procedimiento. 
que, digámoslo, de modo secular definió a los jueces ya no como terceros imparciales ${ }^{7}$, sino como los señores de un proceso unilateral, donde los abogados auxiliaban su labor investigativa y de consuno facilitaban a través de la confesión provocada del imputado la expiación de ese pecado social llamado delito ${ }^{8}$.

Este enfoque, surgido de una historia procesal penal que, en general, concibió a la garantía de la imparcialidad del juzgador como un callejón deteriorado, prácticamente sin salida y de difícil tránsito litigioso, debiera ser progresivamente reemplazado por una concepción coherente con el principio acusatorio que informa al actual proceso penal, atendida la posición neutral que, incluso en la disposición espacial de un tribunal ${ }^{9}$, ubica al juez al centro y por encima de fiscales y defensores.

Sin embargo, con seguridad, son los resabios del pasado los que todavía constituyen una de las fuentes más fecundas a la hora de formular interpretaciones judiciales destinadas a inhibir, eludir y restringir ${ }^{10-11}$ el reclamo efectivo de este derecho sobre el que descansa la más básica regla del debido proceso.

${ }^{7}$ Hernández Duco, Álvaro, La Imparcialidad de los Jueces, Memoria de Prueba para optar al grado de Licenciado en Ciencias Jurídicas y Sociales, Facultad de Derecho de la Universidad de Chile, Santiago, 1990. El autor explica cómo el concepto de imparcialidad del juez construido por los antiguos desapareció bajo el proceso inquisitivo que convirtió al juez en un delegado del soberano y, por lo mismo, inmune a los cuestionamientos de parcialidad.

${ }^{8}$ En su exposición de motivos a la vigente Ley de Enjuiciamiento Criminal de 1882, Alonso Martínez nos recordaba los males de una Justicia Penal vinculada a las ideas del Antiguo Régimen y entre ellos el de la confusión de las funciones de instruir y fallar: "Lo peor de todo es...que el Juez que instruye éste (el sumario), es el mismo que pronuncia la sentencia con todas las preocupaciones y prejuicios que ha becho nacer en su ánimo la instrucción, que, confundido lo civil con lo criminal y abrumados los Jueces de primera instancia por el cúmulo de sus múltiples y variadas atenciones, delegan frecuentemente la práctica de muchas diligencias en el Escribano...". Para decirnos a continuación que "...nuestros Jueces y Magistrados han adquirido el hábito de dar escasa importancia a las pruebas del plenario, formando su convicción con el resultado de las diligencias sumariales...".

${ }^{9}$ Foucault, Michel, Un diálogo sobre el poder y otras conversaciones, Alianza Editorial, Tercera Reimpresión, Madrid, 2007, p. 37.

${ }^{10}$ La experiencia en el trabajo de apoyo a la labor de los Defensores Penales Públicos realizada por la Unidad de Estudios de la Defensoría Regional de Los Lagos demuestra que cada vez que se ha discutido la posibilidad de recusar o implicar a un juez del Tribunal Oral en lo Penal ha existido una cierta resistencia entre los defensores penales públicos a promover incidentes sobre esta materia por el temor de los abogados a la opinión negativa que de esa actuación podría formarse el tribunal y al riesgo aparente o real que ese desfavorable parecer surgido del cuestionamiento de falta de imparcialidad del tribunal afecte su desempeño futuro como defensor penal público o abogado particular ante esa instancia.

${ }^{11}$ El temor a la incomprensión judicial en el ejercicio de la garantía que asegura el derecho al juez imparcial y el riesgo de que el juzgador considere esa actuación como una afrenta personal o como un agravio inmerecido a su honorabilidad parece no ser un problema estrictamente local. Así se desprende del dictamen del Procurador General de la Nación Argentina, quien en el denominado caso Zenzerovich sostuvo que, en primer lugar, es necesario aclarar una cuestión que es reiteradamente confundida por nuestros tribunales: La exigencia de un juez imparcial y, por ende, la facultad de apartar a jueces sospechados de parcialidad, no debe ser confundida con una agresión a la honorabilidad u honestidad de los jueces. Para que los jueces sean personas honestas y honorables, las normas establecen cuáles son los requisitos para su nombramiento, y para el caso que un juez no lo sea se prevén sistemas de remoción.

Sin embargo, un juez honorable no garantiza imparcialidad frente a todos los casos en los que le toca intervenir y esto no es motivo alguno de reproche al juez. Para comprender qué significa la garantía 


\section{Contenido de la garantía de imparcialidad DEL TRIBUNAL}

Este artículo surge de las interrogantes que, como Unidad de Estudios de la Defensoría Regional de Los Lagos, hemos debido enfrentar, hasta ahora, en un territorio de escasa población relativa y de estrecha vida social. Aquello, amén de las consultas planteadas por los prestadores de la defensa penal pública, constituye una permanente fuente de reflexión en torno de la garantía de imparcialidad del juzgador y un fructífero acicate a la hora de buscar interpretaciones racionales que contribuyan a nutrir esta regla de todo juicio justo.

En ese sentido, consideramos esencial esbozar al menos el contenido material más básico de la garantía de la imparcialidad del juez o lo que la doctrina ha definido como la capacidad específica del tribunal ${ }^{12}$, desde que sabemos y nos consta que las situaciones fácticas capaces de conmover o comprometer la necesaria actuación desprejuiciada del juzgador configuran una casuística insondable, sin perjuicio de lo cual nos permitiremos enunciar algunos de los incidentes que sobre esta materia hemos conocido y los procedimientos que estimamos aplicables para su resolución.

\section{1a. Estado Constitucional de Derecho}

Caracterizar el catálogo de potenciales infracciones a la posición súper partes del juez en el proceso penal como una lista no taxativa, es uno de los presupuestos sobre los que se debe pensar esta garantía. Lo anterior se debe fundamentalmente a los efectos provocados por la eclosión del denominado Estado Constitucional de Derecho, que surge a partir de la segunda mitad del siglo $\mathrm{XX}^{13}$ y que reconoce garantías de estructura normativa abierta, con capacidad de ampliar considerablemente el Derecho aplicable a este tipo de conflictos. Un ejemplo de ello es la garantía del debido proceso establecida en nuestra Carta Fundamental, la que se asegura a todas las personas bajo la expresión "procedimiento e investigación racionales y justos" ${ }^{14}$ utilizada en su artículo 19 No 3 y,

de imparcialidad debe partirse de que el temor de imparcialidad es un vicio objetivo del procedimiento y no una mala cualidad subjetiva o personal del juez. En estos términos lo refirió Barberis al comentar el antiguo Código de Proced. Penal: "No hay juez sobre la tierra que pueda sentirse rozado en su persona o menoscabado en su decoro y en el ejercicio de su augusta investidura por una recusación..." (Barberis, Luis A., "Código de Procedimientos en materia Penal", t. 1, De las Recusaciones, Capítulo 1 art. 74", pp. 96-97, Depalma, 1956).

${ }^{12}$ Clariá Olmedo, Jorge, Derecho Procesal Penal, Tomo I, Ed. Rubinzal-Culzoni, Buenos Aires, 2001, p. 294 y ss.

${ }^{13}$ Meroi, Andrea A., "Iura novit curia y decisión imparcial", en Ius et Praxis, año 13, No 2, Universidad de Talca, Chile, p. 379.

${ }^{14}$ El profesor Enrique Evans de la Cuadra sostiene que de modo muy escueto los elementos que constituyen un racional y justo procedimiento son: notificación y audiencia del afectado; presentación de las pruebas, recepción de ellas y su examen; sentencia dictada en plazo razonable; sentencia dictada por un tribunal u órgano imparcial y objetivo y posibilidad de revisión de lo fallado por una instancia superior igualmente imparcial y objetiva. Evans de la Cuadra, Enrique, Los Derechos Constitucionales, Tomo II, Editorial Jurídica de Chile, tercera edición, 2004, Santiago, p. 144. 
a través de cuya luz, advertimos que hablar hoy de juez imparcial dejó de ser un diálogo de pura ley inferior, para elevarse e intentar responder las interrogantes planteadas por la actividad forense directamente desde las garantías constitucionales ${ }^{15}$ y los tratados internacionales sobre derechos humanos ${ }^{16}$.

De modo complementario se hace necesario, además, revisar los procedimientos destinados a prevenir o evitar antes del inicio del juicio la afectación de la garantía de imparcialidad del tribunal oral en lo penal, su capacidad para proteger verdaderamente este aspecto del debido proceso y, por supuesto, el modo de exigir la separación de los magistrados implicados o legalmente recusados, y, en aquellos casos donde la parcialidad de los jueces se ha expresado durante el desarrollo de la audiencia, reconocer y distinguir los instrumentos reparatorios o represivos de la infracción del derecho al juez imparcial, que, como es obvio, operan de modo correctivo y posterior.

Ya dijimos que el artículo $19 \mathrm{~N}^{\circ} 3$ de la Constitución Política del Estado reconoce al debido proceso como una de las garantías informadoras de toda actuación de juzgamiento. Su inciso quinto prescribe que toda sentencia de un órgano que ejerza jurisdicción debe fundarse en un proceso previo legalmente tramitado y agrega que corresponderá al legislador establecer siempre las garantías de un procedimiento y una investigación racionales y justos.

El párrafo anterior de la misma garantía constitucional asegura, también, el derecho al juez natural, imparcial e independiente, al reconocer que nadie puede ser juzgado por comisiones especiales, sino por el tribunal que le señale la ley y que se halle establecido con anterioridad por ésta.

\section{1b. Ausencia de designio anticipado}

Jorge Contesse Singh escribe que uno de los principios fundamentales de esa garantía del debido proceso, como se sabe, es el de imparcialidad del tribunal, según el cual las sentencias pronunciadas por los órganos que ejercen jurisdicción sólo son

15 El Manual de Derecho Internacional de los Derechos Humanos para Defensores Penales Públicos, publicado en diciembre de 2003 por el Centro de Documentación de la Defensoría Penal Pública, sostiene en su página 139 que si bien la Constitución Política del Estado no contiene ninguna referencia expresa sobre imparcialidad del juzgador, advierte que se trata de una garantía directamente relacionada con la independencia judicial asegurada en el artículo 73 de la Carta Fundamental y agrega que el artículo 8.1 de la Convención Americana de Derechos Humanos recoge la garantía de imparcialidad de forma más extensa: "un juez o tribunal competente, independiente e imparcial establecido con anterioridad por la ley".

${ }^{16}$ La Ley de Reforma Constitucional N 18.825 de 17 de agosto de 1989, modificó el artículo $5^{\circ}$ de la Constitución Política del Estado agregando al inciso segundo lo siguiente: Es deber de los órganos del Estado respetar y promover tales derechos garantizados por esta Constitución (derechos esenciales que emanan de la naturaleza humana), así como por los tratados internacionales ratificados por Chile y que se encuentren vigentes. La Constitución Política chilena resuelve en forma clara y categórica que el ejercicio de nuestra soberanía está limitado al respeto de los derechos esenciales que emanen de la naturaleza humana y que es deber de los órganos del Estado respetarlos y promoverlos, sea que estén garantizados por la propia Constitución así como por los tratados internacionales. Quinzio F., Jorge Mario, Tratado de Derecho Constitucional, Tomo II, Editorial LexisNexis, primera edición, 2004, Santiago, pp. 5-6. 
legítimas cuando se dictan en el marco de un procedimiento que no deja dudas acerca de la posición desprejuiciada del tribunal. Su contenido aparece retratado en la esfinge de Iustitia, símbolo romano de la justicia, que junto con sostener la balanza para aquilatar los argumentos de las partes, lleva consigo la espada que brinda imperio a sus decisiones y su vista vendada, como elocuente manifestación de la ausencia de todo interés en decidir el conflicto con juicios ajenos a los ventilados por los litigantes que comparecen a su presencia ${ }^{17}$.

De acuerdo al Diccionario de la Real Academia de la Lengua Española imparcialidad no es otra cosa que la falta de designio anticipado o de prevención en favor o en contra de alguien o algo, que permite juzgar o proceder con rectitud. Es una virtud reconocida normativamente para el bien de los ciudadanos y de la justicia que debe acompañar a la figura y función del juez natural ${ }^{18}$.

Luigi Ferrajoli sostiene que la imparcialidad del juez exige el respeto de condiciones orgánicas y de otras de carácter cultural. Entre las primeras menciona: la imparcialidad en sentido estricto, entendida como ajenidad del juzgador a los intereses de las partes; la independencia, destinada a brindar inmunidad a la labor del juez frente a todo sistema de poderes; y, por último, la naturalidad, que exige la designación y la determinación de las competencias del juez con anterioridad a la perpetración del hecho sometido a juicio. Entre las segundas, sostiene que la imparcialidad, más allá de las garantías institucionales, es un hábito intelectual y moral de quien decide y que se resume en la total y absoluta ausencia de interés personal o privado en el resultado de la causa: nadie debe ser juez o árbitro en su propia causa y por ello -son palabras de Hobbes- "nadie debe ser árbitro si para él resulta aparentemente un mayor provecho, material o espiritual, de la victoria de una parte que de la otra"19.

\section{1c. La estructura triangular del proceso penal}

En buena medida, la actitud de ecuánime indiferencia del juzgador frente a las pretensiones de quienes litigan en su tribunal se refleja en esta estructura triangular que se erige en sello de identidad del proceso penal acusatorio. La organización jurídica triádica es indispensable para garantizar la ajenidad del juez frente a los dos intereses contrapuestos -el de la tutela frente a los delitos representado por la acusación y el de la tutela frente a los castigos inmerecidos representado por la defensa- que además corresponden a los dos fines, perfectamente compatibles en abstracto, pero siempre conflictivos en concreto, que, como se ha visto, justifican el derecho penal ${ }^{20}$.

\footnotetext{
${ }^{17}$ Contesse Singh, Jorge, "Implicancias y recusaciones: el caso del tribunal constitucional. Informe en derecho sobre la inhabilidad constitucional para conocer de un caso en el que se ha vertido opinión pública con anterioridad", en Ius et Praxis, año 13, No 2, Universidad de Talca, Chile, p. 393.

18 Saavedra Rojas, Edgar, Constitución, Derechos Humanos y Proceso Penal, Ediciones Jurídicas Gustavo Ibáñez C., Santafé de Bogotá, Colombia, 1995, p. 122.

${ }^{19}$ Ferrajoli, Luigi, Derecho y razón, Editorial Trotta, Madrid, octava edición, 2006, p. 581.

${ }^{20}$ Ibíd., nota anterior.
} 
Así las cosas, el desinterés institucional y personal del juzgador frente a las peticiones de los intervinientes ${ }^{21}$ sería el epítome de la imparcialidad del tribunal que no sólo aparta al juez de la política criminal impulsada por el Legislador y la Administración, sino que erige a la tutela jurisdiccional ${ }^{22}$ en un contrapoder que controla la legalidad de esas actuaciones del Estado, excluyendo la satisfacción de todo apetito personal de la decisión pronunciada.

Por eso, desde la perspectiva de las partes trabadas en la litis, la neutralidad del órgano llamado a conocer y resolver el conflicto sometido a su conocimiento y fallo presenta dos dimensiones o aspectos susceptibles de ser sometidos a control, precisamente para garantizar una sentencia pronunciada por un órgano efectivamente imparcial.

\section{1d. Dimensiones subjetiva y objetiva de la imparcialidad del juzgador}

Primero habrá que revisar si existen antecedentes para estimar razonablemente que existe o existió en el proceso una afectación de la garantía de imparcialidad del tribunal en su dimensión subjetiva ${ }^{23}$, y, por tanto, es necesario evaluar si hay evidencia suficiente para estimar que la convicción del juez se formó al margen del juicio, por ejemplo, sobre la base de su propia información privada o en virtud de sus particulares intereses comprometidos en el término del pleito, todo lo cual puebla un terreno espiritual prác-

${ }^{21}$ El artículo 12 del Código Procesal Penal prescribe que para los efectos regulados en este Código se considerarán intervinientes en el procedimiento al fiscal, al imputado, al defensor, a la víctima y al querellante, desde que realizaren cualquier actuación procesal o desde el momento en que la ley les permitiere ejercer facultades determinadas.

22 En la causa Rol Ingreso Excma. Corte Suprema 4954-2008 el considerando séptimo de la resolución en ella recaída sostiene: "Que en lo que cabe al derecho a defensa, nuestro Código Procesal Penal, señala en el artículo $8^{\circ}$, cual es el ámbito de la defensa y contempla no sólo el derecho a ser defendido por letrado desde la primera actuación, sino que además, que el imputado tendrá derecho a formular los planteamientos y alegaciones que considere oportunos, así como a intervenir en todas las actuaciones del procedimiento, salvas las excepciones expresamente previstas en este Código.

Esta disposición no es más que una expresión de las garantías fundamentales del ser humano, reconocidas en nuestra Constitución Política, en el artículo 19 y primordialmente en su ordinal tercero, que consagra el derecho de toda persona a la defensa jurídica y la obligación de que toda sentencia de un órgano que ejerza jurisdicción esté fundada en un proceso previo, legalmente tramitado.

Tal derecho a defensa parte por el de a ser oído y a intervenir en el juicio, pues es interesado en los resultados del mismo y puede intervenir en la decisión jurisdiccional que podrá afectar algunos de los bienes jurídicos que tiene, entre ellos su libertad personal, su patrimonio. Asimismo, implica el derecho de contradecir las alegaciones del demandante 0 acusador, a formular sus propias alegaciones destinadas a desvirtuar los cargos formulados en la acusación, a presentar sus pruebas, y a tener un defensor técnico y jurídico" (Derechos Fundamentales y garantías constitucionales, Tomo 2, pág. 300, Humberto Nogueira Alcalá).

Este derecho a contradecir alegaciones y formular las propias, junto a la acreditación de lo reclamado, constituye una expresión de los principios de contradicción y audiencia bilateral, propios de nuestro nuevo sistema procesal penal. La restricción a ese derecho por parte de un tribunal deviene necesariamente en una falta flagrante y grave de su deber de tutela jurisdiccional y una abierta violación al derecho a defensa”.

${ }^{23}$ Montero Aroca, Juan, Sobre la imparcialidad del juez y la incompatibilidad de funciones procesales, Editorial Tirant Lo Blanch, Valencia, 1999, p. 44. 
ticamente inescrutable en el juzgador pero que, sin embargo, puede inferirse de cierta evidencia fáctica o expresarse en actuaciones externas que la develan.

Sobre esta materia, Andrés Bordalí escribe que corresponderá a la parte que se lamenta de la parcialidad del magistrado demostrarla, probando en concreto que la disposición anímica o psicológica del juez y su conducta exteriorizada son síntomas de falta de imparcialidad ${ }^{24}$.

Pero hay también una dimensión objetiva de esta garantía que, a diferencia de aquella subjetiva, no exige efectiva neutralidad al juzgador, sino sólo un comportamiento y posición de indiscutida indiferencia frente a las partes y sus intereses.

Con la imparcialidad objetiva no se trata ya que el juez haya exteriorizado convicción personal alguna ni haya tomado partido previo, sino que estamos frente a un juez que no ofrece garantías suficientes para excluir toda duda legítima al respecto ${ }^{25}$.

En este plano, se busca cautelar la confianza de la sociedad en la correcta administración de justicia. El respeto del aspecto objetivo de la imparcialidad nos recuerda que la mujer del César no sólo debe serlo sino además parecerlo ${ }^{26}$, lo que significa que los jueces deben, no obstante, contar con la confianza de los sujetos que juzgan de modo que éstos ni siquiera alberguen el temor de llegar a tener un juez enemigo o de cualquier modo parcial.

Desde una perspectiva jurisprudencial la distinción entre los aspectos subjetivos y objetivos de la garantía que asegura la imparcialidad del juzgador aparece ya en una resolución del Tribunal Europeo de Derechos Humanos (TEDH) de octubre de 1982 recaída en el ya famoso y renombrado caso Piersack, oportunidad en la que de modo unánime sus miembros dijeron: "Si la imparcialidad supone de ordinario la ausencia de prejuicios, su existencia se puede apreciar de distintas formas. Se puede distinguir entre un enfoque subjetivo que trata de averiguar la convicción personal de un determinado Juez en un caso concreto $y$ en un enfoque objetivo que trata de determinar si éste ofrece garantías suficientes para excluir una legítima duda al respecto".

En este caso resuelto por el TEDH, el Presidente de la Audiencia era el señor Van del Valle, quien con anterioridad había dirigido una sección del Ministerio Fiscal que llevó a cabo las investigaciones sin intervenir personalmente en esa labor. Si bien se dijo que de la imparcialidad y corrección del señor Van del Valle no se duda mientras no se demuestre lo contrario, se consideró aquello insuficiente como garantía de imparcialidad.

Joaquín González Casso, a propósito del análisis que realiza de esta causa, sostiene que en este punto las apariencias son ciertamente importantes. Afirma que si bien desde la óptica subjetiva puede haber imparcialidad, no la hay desde una apreciación objetiva, dado que la intervención del Presidente del Tribunal sentenciador previamente

${ }^{24}$ Bordalí Salamanca, Andrés, "El derecho fundamental a un tribunal independiente e imparcial en el ordenamiento jurídico chileno", en Revista de Derecho de la Pontificia Universidad Católica de Valparaíso, $2^{\circ}$ Semestre de 2009, p. 273.

${ }^{25}$ Bordalí Salamanca, Andrés. Op. cit., en n. 24, p. 273.

${ }^{26}$ Saavedra Rojas, Edgar, Constitución, Derechos Humanos y Proceso Penal, Ediciones Jurídicas Gustavo Ibáñez C., Santafé de Bogotá, Colombia, 1995, p. 123. 
como acusador fiscal, aunque fuera esporádica o indirecta, hizo que su imparcialidad suscitara dudas ${ }^{27}$.

También el Tribunal Constitucional Español (TC) ha reconocido esta extensión a la garantía de imparcialidad. En su comentario a las sentencias de esa instancia $\mathrm{N}^{\circ}$ 145/1988 y No 164/1988, Luis Rodríguez Ramos sostiene que quien dicta una sentencia debe ser ajeno a filias y fobias hacia las partes -imparcialidad subjetiva-cuanto a la existencia de apariencias y prejuicios que puedan suponer obstáculos para una decisión neutral y justa -imparcialidad objetiva- ${ }^{28}$.

Agrega que el Tribunal Constitucional Español, adhiriendo a la doctrina del Tribunal Europeo de Derechos Humanos, insiste "en la importancia que en esta materia tienen las apariencias, de forma que debe abstenerse todo juez del que pueda temerse legítimamente una falta de imparcialidad, pues va en ello la confianza que los Tribunales de una sociedad democrática han de inspirar a los justiciables, comenzando en lo penal, por los mismos acusados..."29.

\section{1e. Un pronunciamiento de la Comisión Interamericana de Derechos Humanos}

En América Latina sin haber alcanzado aún el desarrollo jurisprudencial logrado por el TEDH, ha existido reconocimiento del alcance objetivo de la garantía. Por ejemplo, la Comisión Interamericana de Derechos Humanos en su informe 127/01 de 3 de diciembre de 2001 en el caso Joseph Thomas. En aquel caso, Jamaica sostuvo que el juez de primera instancia violó su obligación de imparcialidad al instruir al jurado, antes de sus deliberaciones, en los siguientes términos: "Bien, no preveo que tengan algún problema en el sentido de que fue el acusado quien lo mató, quizá a esta altura deba indicar el principio de lo que se conoce como intención común" $"$.

La Comisión sostiene que entre los requisitos de un juicio justo (...) se encuentra la imparcialidad de parte del tribunal y, en el contexto de un proceso penal, que se presuma la inocencia del acusado hasta probarse su culpabilidad. El fallo concluye refiriéndose a los criterios de Derecho Internacional relativos al peligro concreto de parcialidad: "Los comentarios del juez de primera instancia fueron de un tenor tal que, aun leídos conjuntamente con sus instrucciones desde el punto de vista del derecho, dan lugar a un peligro claro y real de parcialidad del tribunal". Su recomendación fue la invalidación de la condena ${ }^{31}$.

\footnotetext{
${ }^{27}$ González Casso, Joaquín, Sobre el derecho al juez imparcial, Editorial Dykinson, España, 2004, pp. 16 y 17.

28 Rodríguez Ramos, Luis, Justicia Penal. Comentarios de sentencias del tribunal constitucional y del tribunal supremo, Colección Iure, dirigida por Jacobo López Barja de Quiroga, Ediciones Akal, Madrid, 1990, p. 11.

${ }^{29}$ Sentencia del Tribunal Constitucional Español de 12 de julio de 1988 N 145/1988.

${ }^{30}$ Manual de Derecho Internacional de los Derechos Humanos para Defensores Penales Públicos, Ed. Centro de Documentación de la Defensoría Penal Pública, Santiago, diciembre de 2003, pp. 143-144.

${ }^{31}$ Ibid., nota anterior.
} 


\section{LA EXPERIENCIA FORENSE EN LA DISCUSIÓN SOBRE IMPARCIALIDAD}

Esbozado el contenido conceptual de la garantía de imparcialidad del tribunal, revisaremos algunos de los casos que a nivel local han suscitado discusión sobre este punto, para, finalmente, y como adelantábamos al inicio del artículo, revisar los procedimientos precautorios y de protección previa de esta garantía, como también aquellos mecanismos procesales de represión destinados a remediar su efectiva lesión durante el juzgamiento y la decisión del conflicto.

\section{2a. Comentarios de prensa del Juez Presidente del Tribunal Oral en lo Penal de Puerto Montt formulados antes del juicio del llamado caso Piccardo}

Benedicto Piccardo Olivos, 78 años de edad, sacerdote, rector del Liceo de Hombres e Hijo Ilustre de la ciudad de Puerto Montt, fue encontrado muerto en su departamento, amordazado y con sus extremidades atadas el pasado 16 de enero de 2006. Durante sus funerales fueron miles los ciudadanos, estudiantes, ex alumnos, amigos y feligreses que participaron de las exequias de la víctima.

Dos días antes del inicio del juicio oral programado para conocer de estos hechos que fueron calificados como robo con homicidio por el Ministerio Público, el Juez Presidente del Tribunal Oral en lo Penal de Puerto Montt y de la sala que juzgaría a los dos acusados del crimen concedió una entrevista al diario El Llanquibue que publicaba lo siguiente: "En cuanto a la seguridad fuera del tribunal, el magistrado advirtió que es muy probable que los familiares de los imputados y los amigos del sacerdote asesinado puedan encontrarse a la entrada del recinto..."32.

En el mismo artículo se publica que el Juez manifestó que la comunidad debe estar tranquila, pues se va a cumplir con lo dispuesto por la ley, afirmaciones que a juicio de la defensa crearon un peligro real y objetivo de parcialidad, toda vez que la víctima era el rector del Liceo de Hombres de Puerto Montt e Hijo Ilustre de la misma comunidad a la que tranquilizaba el magistrado a través de su entrevista concedida al diario El Llanquibue, sin que públicamente expresara igual cuidado con las garantías de los acusados.

Por último, en la parte inferior de la misma página del diario ya referido, en recuadro destacado, apareció una nota titulada "Magistrado incluso ha sentenciado a Pena de Muerte", donde la prensa subrayó la severidad de ese magistrado, aspecto que fue considerado por uno de los acusados como un peligro de falta de imparcialidad del juzgador, según argumentó en audiencia su defensa técnica.

\section{2ai. Incidente de inhabilitación del Juez Presidente de la sala}

Una vez iniciado el juicio oral del caso Piccardo, y en forma previa a la realización de los alegatos de apertura, la defensa de los acusados en virtud de lo previsto en el

${ }^{32}$ Edición del diario El Llanquibue, viernes 13 de abril de 2007, página A 11, nota titulada "Juez explicó detalles de juicio oral". 
artículo 76 del Código Procesal Penal ${ }^{33}$ promovió un incidente destinado a inhabilitar al Juez Presidente del Tribunal Oral y de la sala, argumentando que uno de los acusados había leído la nota de prensa publicada dos días atrás en el diario El Llanquibue donde el magistrado se refería a la víctima como el sacerdote asesinado, afirmación que había hecho surgir en los imputados el fundado temor de enfrentar un juzgamiento sin suficientes garantías de imparcialidad ${ }^{34}$.

El incidente fue rechazado en forma unánime por el tribunal, bajo el argumento de que esas expresiones no fueron emitidas por el juez, sino por el periodista a cargo de la redacción del artículo, razón por la cual se desechó la solicitud de inhabilitación de uno de los jueces en forma previa al juicio.

Conocida la sentencia que condenó a los dos acusados como autores de robo con homicidio a penas de 20 y 15 años de presidio mayor, la defensa penal pública que representaba a los sentenciados interpuso un recurso de nulidad para ante la Excma. Corte Suprema, fundado, entre otras causales, en la prevista en el artículo 373 a) del Código Procesal Penal ${ }^{35}$ por estimar que los comentarios de prensa atribuidos al Juez Presidente del Tribunal Oral en lo Penal de Puerto Montt, quien se refería a la víctima como el sacerdote asesinado, infringieron la garantía que asegura el derecho al juez imparcial consagrada en el artículo 8.1 de la Convención Americana de Derechos Humanos ${ }^{36}$ y artículo $19 \mathrm{~N}^{\circ} 3$ inciso $4^{\circ}$ de la Constitución Política del Estado (debido proceso).

En la fundamentación de su solicitud de invalidación del juicio y la sentencia, la defensa de los condenados reivindicó como causal de nulidad la fuerza vinculante que para el Estado tienen los derechos fundamentales reconocidos a la persona humana, entre

${ }^{33}$ Artículo 76 inciso $2^{\circ}$ del Código Procesal Penal: Cuando los hechos que constituyeren la causal de implicancia y recusación llegaren a conocimiento de la parte con posterioridad al vencimiento del plazo previsto en el inciso anterior $y$ antes del inicio del juicio oral, el incidente respectivo deberá ser promovido al iniciarse la audiencia de juicio oral.

En esta causa RIT 13-2007 del Tribunal Oral en lo Penal de Puerto Montt las expresiones atribuidas por el diario El Llanquibue al Juez Presidente de esa instancia, quien aparecía públicamente calificando de asesinato la muerte del sacerdote Benedicto Piccardo, fueron publicadas tres días antes del inicio del juicio oral y, por eso, se solicitó la inhabilidad de ese magistrado al inicio de la audiencia de juicio oral, tal como lo prescribe la norma precedentemente citada.

${ }^{34}$ Días previos al inicio del juicio oral también la radio Bío-Bío informó de un cambio en la integración original del Tribunal Oral en lo Penal de Puerto Montt por razones de mejor servicio jurisdiccional que jamás fue explicado y en cuya virtud se liberó a uno de los jueces y se nombró a otra jueza, modificación que fue informada por el periodista como un endurecimiento del tribunal que juzgaría a los acusados del robo con homicidio de Benedicto Piccardo y que también llegó a oídos de los acusados incrementando en ellos un razonable temor de enfrentar un juzgamiento sin garantías de imparcialidad o neutralidad atendida la posición de la víctima en la comunidad de Puerto Montt y las eventuales relaciones que en una comunidad tan pequeña pudo tener en vida con los jueces de la misma ciudad.

35 Artículo 373 del Código Procesal Penal: Procederá la declaración de nulidad del juicio oral y de la sentencia:

a) Cuando, en cualquier etapa del procedimiento o en el pronunciamiento de la sentencia, se bubieren infringido sustancialmente derechos o garantías asegurados por la Constitución o por los tratados internacionales ratificados por Chile que se encuentren vigentes...

${ }^{36}$ El artículo 8.1 de la Convención Americana de Derechos Humanos establece que toda persona tiene derecho a ser oída con las debidas garantías y dentro de un plazo razonable, por un juez o tribunal competente, independiente e imparcial, establecido con anterioridad por la ley, en la sustanciación de cualquier acusación penal formulada contra ella. 
ellos el que asegura una decisión pronunciada por un juez imparcial, para lo cual citó en apoyo de su pretensión al profesor Miguel Ángel Fernández González, quien sostiene que el Código Procesal Penal en su artículo 373 letra a) ordena a los operadores jurídicos aplicar directamente la Constitución Política del Estado y los Tratados Internacionales sobre Derechos Humanos, vigentes en Chile, dotando no sólo a aquélla sino también a éstos de vigor jurídico inmediato ${ }^{37}$.

\section{2aii.Pronunciamiento de la Excma. Corte Suprema}

De la resolución de la Excma. Corte Suprema que rechazó el recurso de nulidad impetrado por la Defensa de los acusados ${ }^{38}$, es posible extraer para este caso concreto los siguientes criterios de relevancia:

i) La imparcialidad del tribunal en nuestro ordenamiento jurídico, al menos desde su vertiente objetiva y de proscripción de las sospechas de prejuicio, tiene un contenido notablemente más estrecho que el reconocido por el derecho internacional, al limitarse únicamente a la facultad legal de reclamar la inhabilidad de los jueces a través de la invocación de las causales de implicancia y recusación ${ }^{39}$ establecidas en los artículos $195^{40}$ y $196^{41}$ del Código Orgánico de Tribunales.

37 Fernández González, Miguel Ángel, La Nueva Justicia Penal frente a la Constitución, Editorial LexisNexis, primera edición, junio, 2006, Santiago, p. 21.

${ }^{38}$ Resolución de la Excma. Corte Suprema de fecha 12 de julio de 2007 recaída en la causa Rol Ingreso $\mathrm{N}^{\circ}$ 2426-2007.

${ }^{39}$ Rol Ingreso Excma. Corte Suprema 2426-2007. Considerando décimo cuarto: "Que en materia de inhabilitación de los jueces del tribunal del juicio oral, el artículo 76 del Código Procesal Penal gobierna el procedimiento para su formalización, manteniéndose, en todo, las causales taxativas que al efecto contemplan los artículos 195 y 196 del Código Orgánico de Tribunales".

40 Art. 195 del Código Orgánico de Tribunales: Son causas de implicancia: $1^{\circ}$. Ser el juez parte en el pleito o tener en él interés personal, salvo lo dispuesto en el número 18 del artículo siguiente; $2^{\circ}$. Ser el juez consorte o pariente consanguíneo legítimo en cualquiera de los grados de la línea recta y en la colateral hasta el segundo grado inclusive, o ser padre o hijo natural o adoptivo de alguna de las partes o de sus representantes legales; $3^{\circ}$. Ser el juez tutor o curador de alguna de las partes, o ser albacea de alguna sucesión, o síndico de alguna quiebra, o administrador de algún establecimiento, o representante de alguna persona jurídica que figure como parte en el juicio; $4^{\circ}$. Ser el juez ascendiente o descendiente legítimo, padre o hijo natural o adoptivo del abogado de alguna de las partes $; 5^{\circ}$ Haber sido el juez abogado o apoderado de alguna de las partes en la causa actualmente sometida a su conocimiento o haber intervenido en ella como mediador; $6^{\circ}$. Tener el juez, su consorte, ascendientes o descendientes legítimos padres o hijos naturales o adoptivos, causa pendiente en que deba fallar como juez alguna de las partes; $7^{\circ}$. Tener el juez, su consorte, ascendientes o descendientes legítimos, padres o hijos naturales o adoptivos, causa pendiente en que se ventile la misma cuestión que el juez debe fallar; $8^{\circ}$. Haber el juez manifestado su dictamen sobre la cuestión pendiente con conocimiento de los antecedentes necesarios para pronunciar sentencia, y $9^{\circ}$. Ser el juez, su consorte, o alguno de sus ascendientes o descendientes legítimos, padres o hijos naturales o adoptivos, herederos instituido en testamento por alguna de las partes. Lo dicho en este artículo es sin perjuicio de lo dispuesto en el artículo 1324 y en los incisos tercero y cuarto del artículo 1325 del Código Civil. Respecto de los jueces con competencia criminal, son causas de implicancia, además, las siguientes: $1^{\circ}$ Haber intervenido con anterioridad en el procedimiento como fiscal o defensor; $2^{\circ}$ Haber formulado acusación como fiscal, o haber asumido la defensa, en otro procedimiento seguido contra el mismo imputado, y $3^{\circ}$ Haber actuado el miembro del tribunal de juicio oral en lo penal como juez de garantía en el mismo procedimiento.

${ }^{41}$ Art. 196 del Código Orgánico de Tribunales. Son causas de recusación: $1^{\circ}$. Ser el juez pariente consanguíneo simplemente ilegítimo en toda la línea recta y en la colateral hasta el cuarto grado inclusive, o consanguíneo 
ii) Los cuestionamientos a la falta de imparcialidad del tribunal sólo pueden reclamarse del modo preventivo consagrado en el artículo 76 del Código Procesal Penal que obliga a promover este incidente con antelación al inicio del juicio oral y, por regla general, dentro de los tres días siguientes a la notificación de la resolución que fija fecha para el juicio oral ${ }^{42}$.

iii) El Tribunal competente para conocer del incidente de inhabilitación o falta de imparcialidad de los jueces es el mismo tribunal que conocerá del litigio, de acuerdo al ya citado artículo 76 del Código Procesal Penal ${ }^{43}$. No hubo pronunciamiento sobre las alegaciones de la defensa que postulaba que las implicancias

legítimo en la línea colateral desde el tercero hasta el cuarto grado inclusive, o afín hasta el segundo grado también inclusive, de alguna de las partes o de sus representantes legales; $2^{\circ}$. Ser el juez ascendiente o descendiente ilegítimo, hermano o cuñado legítimo o natural del abogado de alguna de las partes; $3^{\circ}$. Tener el juez superior alguno de los parentescos designados en el inciso precedente o en el número $4^{\circ}$ del artículo 195 , con el juez inferior que hubiere pronunciado la sentencia que se trata de confirmar o revocar; $4^{\circ}$. Ser alguna de las partes sirviente, paniaguado o dependiente asalariado del juez, o viceversa; $5^{\circ}$. Ser el juez deudor o acreedor de alguna de las partes o de su abogado; o serlo su consorte o alguno de sus ascendientes, descendientes o parientes colaterales dentro del segundo grado. Sin embargo, no tendrá aplicación la causal del presente número si una de las partes fuere alguna de las instituciones de previsión fiscalizadas por la Superintendencia de Seguridad Social, la Asociación Nacional de Ahorro y Préstamo, o uno de los Servicios de Vivienda y Urbanización, a menos que estas instituciones u organismos ejerciten actualmente cualquier acción judicial contra el juez o contra alguna otra de las personas señaladas o viceversa. $6^{\circ}$. Tener alguno de los ascendientes o descendientes simplemente ilegítimos del juez o los parientes colaterales del mismo dentro del segundo grado, causa pendiente que deba fallar como juez alguna de las partes; $7^{\circ}$. Tener alguno de los ascendientes o descendientes simplemente ilegítimos del juez o los parientes colaterales del mismo dentro del segundo grado, causa pendiente en que se ventile la misma cuestión que el juez deba fallar; $8^{\circ}$. Tener pendientes alguna de las partes pleito civil o criminal con el juez, con su consorte, o con alguno de sus ascendientes, descendientes o parientes colaterales dentro del segundo grado. Cuando el pleito haya sido promovido por alguna de las partes, deberá haberlo sido antes de la instancia en que se intenta la recusación; $9^{\circ}$. Haber el juez declarado como testigo en la cuestión actualmente sometida a su conocimiento;10. Haber el juez manifestado de cualquier modo su dictamen sobre la cuestión pendiente, siempre que lo hubiere hecho con conocimiento de ella;11. Ser alguno de los ascendientes o descendientes ilegítimos del juez o alguno de sus parientes colaterales dentro del segundo grado, instituido heredero en testamento por alguna de las partes;12. Ser alguna de las partes heredero instituido en testamento por el juez; 13 . Ser el juez socio colectivo, comanditario o de hecho de alguna de las partes, serlo su consorte o alguno de los ascendientes o descendientes del mismo juez, o alguno de sus parientes colaterales dentro del segundo grado;14. Haber el juez recibido de alguna de las partes un beneficio de importancia, que haga presumir empeñada su gratitud;15. Tener el juez con alguna de las partes amistad que se manifieste por actos de estrecha familiaridad;16. Tener el juez con alguna de las partes enemistad, odio o resentimiento que haga presumir que no se halla revestido de la debida imparcialidad;17. Haber el juez recibido, después de comenzado el pleito, dádivas o servicios de alguna de las partes, cualquiera que sea su valor o importancia, y18. Ser parte o tener interés en el pleito una sociedad anónima de que el juez sea accionista. No obstante lo dispuesto en el inciso precedente, no constituirá causal de recusación la circunstancia de que una de las partes fuere una sociedad anónima abierta. Lo prevenido en el inciso anterior no regirá cuando concurra la causal señalada en el $\mathrm{N}^{\circ} 8$ de este artículo. Tampoco regirá cuando el juez, por sí solo o en conjunto con alguna de las personas indicadas en el numerando octavo, fuere dueño de más del diez por ciento del capital social. En estos dos casos existirá causal de recusación.

42 Rol Ingreso Excma. Corte Suprema 2426-2007. Considerando décimo quinto: ... “y, en cuanto a la oportunidad, también perentoriamente se indica que deberán plantearse, a más tardar, dentro de los tres días siguientes a la notificación de la resolución que fijare fecha para el juicio oral, las que se resolverán con antelación al inicio de la respectiva audiencia; o bien, al inicio del juicio oral, en incidente previo, si los hechos que constituyeren la causal de implicancia o recusación llegaren a conocimiento de la parte con posterioridad al vencimiento del plazo previsto en el inciso primero de la disposición en comento".

43 Rol Ingreso Excma. Corte Suprema 2426-2007 Considerando décimo quinto: "Que en este contexto, el tribunal llamado a decidir acerca de tales solicitudes de inhabilitación es aquel a quien incumbe conocer del litigio, según expresamente dispone la norma procesal citada en el fundamento precedente..." 
y recusaciones de jueces de tribunales colegiados deben resolverse por el mismo tribunal, pero con exclusión de aquél de sus miembros objeto del cuestionamiento, tal como lo prescribe el artículo 203 del Código Orgánico de Tribunales ${ }^{44}$, todo lo cual será materia de un somero análisis cuando se aborden más adelante los mecanismos procesales preventivos y represivos de infracción a la garantía de imparcialidad.

En cuanto al fondo, la Excma. Corte Suprema indicó que las expresiones adjudicadas por la prensa al Juez Presidente del Tribunal Oral en lo Penal de Puerto Montt no revelan indicio o animadversión que pudiere importar una eventual afectación de los derechos de los incriminados, agregando que en lo que se refiere al extracto de la publicación que afirma que el juez calificó de asesinato la muerte del sacerdote, no se le dará valor alguno, pues de la prueba aportada por el Ministerio Público ha quedado en evidencia que se le atribuyeron al magistrado expresiones que no ha manifestado y que son de exclusiva responsabilidad del periodista autor de la nota informativa.

A nuestro juicio, lo anterior viene a evidenciar que las apariencias de imparcialidad objetiva del tribunal aún presentan en nuestra legislación y jurisprudencia un alcance nítidamente más estrecho que el reconocido por los tratados internacionales sobre derechos humanos.

No se puede perder de vista que en el caso Piccardo fue uno de los acusados quien, en virtud de lo publicado por la prensa antes del juicio, desconfió de la imparcialidad del tribunal y en forma previa al inicio del juicio instruyó a su defensa en el sentido de plantear que las expresiones adjudicadas por el diario El Llanquibue al Presidente de la Sala del Tribunal Oral en lo Penal de Puerto Montt no aseguraban una imagen, ni mucho menos una impresión desinteresada y libre de ilegítimos prejuicios durante el juzgamiento.

\section{2b. Pronunciamiento previo en torno a la necesidad de imponer al acusado la medida cautelar de prisión preventiva}

Probablemente una de las situaciones paradigmáticas de compromiso de la imparcialidad objetiva del juzgador se refiere a los casos en que el Tribunal Oral en lo Penal, llamado a conocer y fallar una acusación fiscal, debe pronunciarse en forma previa al inicio del juicio sobre las solicitudes referidas a la necesidad de decretar la prisión preventiva o de revisar su prolongación en el tiempo, revocación o conveniencia de sustituirla por otras cautelares $^{45}$.

${ }^{44}$ Art. 203 del Código Orgánico de Tribunales. De la implicancia de jueces que sirven en tribunales colegiados conocerá el tribunal mismo con exclusión del miembro o miembros de cuya implicancia se trata.

${ }^{45}$ Art. 142 del Código Procesal Penal: La solicitud de prisión preventiva podrá plantearse verbalmente en la audiencia de formalización de la investigación, en la audiencia de preparación de juicio oral o en la audiencia de juicio oral. 
En todas estas hipótesis, el tribunal debe conocer y pronunciarse antes del juzgamiento sobre los antecedentes que justifican la existencia del delito y que permiten presumir fundadamente la participación del imputado como autor, cómplice o encubridor ${ }^{46}$.

Este tipo de situaciones trae a colación la doctrina desarrollada por el Tribunal Europeo de Derechos Humanos, entre otros, en el caso "Hauschildt" de 1989, oportunidad en la que el demandante reclamó ante esa instancia que el juez que presidió el juicio oral, con anterioridad ratificó en diversas oportunidades su prisión provisional, afectando, así, su derecho a ser juzgado por un tribunal imparcial.

Si bien en su resolución de 24 de mayo de 1989 el Tribunal Europeo de Derechos Humanos sostuvo que, en general, el mero hecho de que un juez haya dictado resoluciones antes del juicio, especialmente sobre la libertad provisional del imputado, no basta para justificar los temores sobre su imparcialidad, en este caso sí fue así, porque el juez prorrogó la privación de libertad de carácter cautelar sobre la base de sospechas confirmadas de que el imputado había cometido un delito de los perseguibles de oficio por el Ministerio Público ${ }^{47}$.

En el caso Paillaleve-Mancilla, causa RIT 25-2005, por el delito de parricidio de un recién nacido, seguida ante el Tribunal Oral en lo Penal de Puerto Montt en contra de sus dos padres, la defensa penal pública que los representaba promovió un incidente de inhabilitación ${ }^{48}$ de dos de los jueces que, por resolución de siete de septiembre de dos mil cinco, fueron llamados a formar sala de juicio oral en la ciudad de Puerto Montt, en

Art. 144 del Código Procesal Penal: La resolución que ordenare o rechazare la prisión preventiva será modificable de oficio o a petición de cualquiera de los intervinientes, en cualquier estado del procedimiento.

Art. 145 del Código Procesal Penal: En cualquier momento del procedimiento el tribunal, de oficio o a petición de parte, podrá substituir la prisión preventiva por alguna de las medidas...(La expresión el tribunal utilizada en esta norma de acuerdo a lo previsto en el artículo 69 del mismo texto legal comprende también al Tribunal Oral en lo Penal).

${ }^{46}$ Una interpretación sistemática de las facultades del Tribunal Oral en lo Penal para pronunciarse sobre solicitudes referidas a prisión preventiva permite postular que está acotada a la hipótesis de los artículos 33 y 347 del Código Procesal Penal, interpretación que evita comprometer artificialmente la imparcialidad del juzgador antes del inicio del juicio, desde que esas normas no exigen discutir ni el presupuesto material del delito, ni tampoco las presunciones fundadas de participación del imputado, porque la primera se acota a los problemas de comparecencia a la audiencia y la segunda opera cuando ya se ha pronunciado veredicto absolutorio.

${ }^{47}$ Joaquín González Casso en ob. cit, p. 21, sostiene que la conclusión del Tribunal Europeo de Derechos Humanos es clara en el sentido de que la adopción o prórroga de medidas cautelares por el Juez o Tribunal destinado a juzgar no supone "per se" la violación del derecho al juez imparcial, siempre que se fundamente en razones extrañas al fondo del asunto (riesgo de fuga, gravedad de la imputación formulada por la acusación, etc), pero podría suponer la violación de la garantía de imparcialidad la adopción de una medida de prisión fundada exclusivamente en la existencia de indicios racionales de criminalidad a que se refiere el artículo 503 de la Ley de Enjuiciamiento Criminal, siempre que entendamos que esos indicios equivalen a lo que el Tribunal Europeo de Derechos Humanos denomina "particularmente confirmada sospecha".

${ }^{48} \mathrm{El}$ incidente se fundó en la causal de implicancia consagrada en el $\mathrm{N}^{\circ} 8$ del artículo 195 del Código Orgánico de Tribunales y que se configura al haber el juez manifestado su dictamen sobre la cuestión pendiente con conocimiento de los antecedentes necesarios para pronunciar sentencia. 
atención a que con anterioridad les había correspondido pronunciarse sobre la necesidad de prolongar la prisión preventiva que afectaba a uno de los acusados ${ }^{49}$.

En su solicitud ${ }^{50}$ la defensa penal pública invocó, además de la causal de implicancia del artículo 195 No 8 del Código Orgánico de Tribunales, diversas disposiciones sobre tratados internacionales sobre derechos humanos ${ }^{51}$ y una cita de la obra de Julio Maier, donde el procesalista argentino recoge la doctrina del Tribunal Constitucional Español que reza: "...Ocurre que la actividad instructora, en cuanto pone al que la lleva a cabo en contacto directo con el acusado y con los hechos y datos que deben servir para averiguar el delito y sus posibles responsables, puede provocar en el ánimo del instructor, incluso a pesar de sus mejores deseos, prejuicios e impresiones a favor o en contra del acusado que influyan a la bora de sentenciar. Incluso aunque ello no suceda es difícil evitar la impresión de que el juez no acomete la función de juzgar sin la plena imparcialidad que le es exigible"52.

\section{2bi. Exclusión de los jueces cuestionados del conocimiento y decisión del incidente de implicancia}

Uno de los aspectos interesantes de este incidente sobre inhabilitación de dos de los jueces del Tribunal Oral en lo Penal de Puerto Montt se refiere al tribunal competente para conocerlo y fallarlo, luego de que esa instancia acogiera la solicitud de la defensa que, de acuerdo a lo prevenido en el artículo 203 del Código Orgánico de Tribunales,

${ }^{49}$ En esta causa se realizó un primer juicio oral que se anuló de pleno derecho de conformidad con lo dispuesto en el inciso final del artículo 76 del Código Procesal Penal, luego que una de las juezas fruto de una licencia médica debiera ausentarse de la audiencia de juicio oral y los otros dos jueces no lograran unanimidad para pronunciar la sentencia definitiva, desde que uno de ellos estuvo por absolver a los acusados y el otro por condenar. Con ese antecedente, la defensa de los acusados de conformidad con lo dispuesto en el artículo 145 del Código Procesal Penal una vez pronunciado el veredicto pidió la revisión de la prisión preventiva de uno de los acusados, para lo cual se formó una nueva sala del Tribunal Oral en lo Penal de Puerto Montt, precisamente en atención a la dispersión de votos de los jueces que conocieron por primera vez de la acusación fiscal, la que fue integrada en esta oportunidad por dos de los jueces que luego fueron designados para conocer en un segundo juicio oral de la formulación de cargos promovida por el Ministerio Público.

${ }^{50}$ Durante la audiencia de conocimiento del incidente de inhabilidad de los jueces del Tribunal Oral en lo Penal de Puerto Montt, el defensor penal público de la causa sostuvo que se han realizado una serie de reformas para evitar la contaminación del Tribunal Oral en lo Penal. El antiguo artículo 281 del Código Procesal Penal, antes del 12 de julio de 2002, señalaba que el juez de garantía remitirá conjuntamente con el auto de apertura, los demás documentos pertinentes. Hubo un auto acordado de la Corte Suprema que señaló a solicitud de una petición que hizo el Fiscal Nacional en enero de 2002, qué se entiende por los "demás documentos a acompañar”, oportunidad en la que el máximo tribunal del país señaló que debían acompañarse todos los registros del juez de garantía, formalización, revisión o discusión de prisión preventiva, auto de apertura y audiencia de preparación de juicio oral. En julio de 2002 se deroga esa norma y se mantiene que se deberá remitir al Tribunal Oral en lo Penal sólo copia del auto de apertura de juicio oral, a fin de evitar la contaminación de los jueces del Tribunal Oral.

51 Artículos 14.1 del Pacto Internacional sobre Derechos Civiles y Políticos y 8.1 de la Convención Americana de Derechos Humanos.

52 Maier, Julio, Derecho Procesal Penal, Fundamentos, Editores del Puerto, $2^{\text {a }}$ edición, Buenos Aires, 2002, pp. 739, 752, 756, 757. 
sostuvo que de la implicancia de jueces que sirven en tribunales colegiados debe conocer el mismo tribunal, con exclusión del miembro o miembros de cuya implicancia se trata.

Recordemos que, en el caso Piccardo, la Excma. Corte Suprema sostuvo que, de conformidad con lo prescrito en el artículo 76 del Código Procesal Penal, la competencia para resolver las solicitudes de inhabilitación de los jueces del Tribunal Oral en lo Penal es de la misma instancia que conocerá del litigio. Y no se pronunció sobre la necesidad de excluir al juez cuestionado del conocimiento y fallo del incidente referido a su eventual marginación del juicio.

La norma del Código Procesal Penal no exige en ninguno de sus incisos la exclusión de los implicados para resolver esta cuestión previa, pero tampoco lo proscribe. En consecuencia, quedó abierta la posibilidad de que esta disposición prevalezca por sobre aquélla contenida en el artículo 203 del Código Orgánico de Tribunales ${ }^{53}$ o bien que se trate de normas simplemente complementarias. Aclarar esta situación es especialmente importante luego de que la Excma. Corte Suprema desestimara la solicitud de nulidad planteada por la defensa de los condenados por el robo con homicidio de Benedicto Piccardo, precisamente porque no se pronunció sobre este problema. En este caso la defensa objetó en el juicio que el incidente relativo a la parcialidad objetiva del Juez Presidente del Tribunal Oral en lo Penal de Puerto Montt fuera resuelto sin su exclusión previa. El tribunal, con el voto del juez que de acuerdo a la defensa era inhábil, rechazó el incidente.

En lo que se refiere al fondo de la solicitud de inhabilitación de dos de los jueces que conocerían del juicio oral en el caso Paillaleve-Mancilla, por votación de mayoría los magistrados no implicados, en su resolución de 14 de septiembre de 2005, estimaron que, con ocasión del debate sobre prisión preventiva de los acusados, el Tribunal Oral en lo Penal de Puerto Montt al haber tomado conocimiento del contenido de declaraciones de testigos y de informes periciales se colocó en la situación de implicancia señalada por la defensa, y, en ese sentido, se declaró la inhabilitación solicitada de conformidad al artículo 195 No 8 del Código Orgánico de Tribunales.

Entre los argumentos que la decisión tuvo en consideración para acoger la implicancia de dos de los jueces designados para conocer del juicio oral, figuró, precisamente, la modificación introducida al artículo 281 del Código Procesal Penal por la Ley N 19.815 de 11 de julio de 2002 que eliminó la posibilidad de que los jueces de garantía remitieran a los tribunales de juicio oral en lo penal cualquier antecedente distinto del auto de apertura de juicio oral, así como también la expresa prohibición de invocar como medios de prueba o dar lectura durante la audiencia de juicio oral a los registros y demás documentos que dieren cuenta de diligencias o actuaciones realizadas por la Policía o el Ministerio Público, según lo prescrito en el inciso primero del artículo 334 del mismo texto legal.

53 Art. 203 del Código Orgánico de Tribunales: De la implicancia de jueces que sirven en tribunales colegiados conocerá el tribunal mismo con exclusión del miembro o miembros de cuya implicancia se trata. 
El voto de minoría, en cambio, estuvo por rechazar la solicitud de implicancia de los dos jueces del Tribunal Oral en lo Penal de Puerto Montt, al sostener que la revisión de la prisión preventiva por parte del Tribunal de Juicio Oral en lo Penal es una facultad propia, reconocida por el artículo 18 letra b) del Código Orgánico de Tribunales y cuyos límites y alcances difieren sustancialmente de la apreciación y valoración de la prueba en que debe fundarse la sentencia definitiva en que se resuelve un juicio oral ${ }^{54}$.

\section{2c. Interrogatorios de los Jueces del Tribunal Oral en lo Penal y facultad del inciso $4^{\circ}$ del artículo 329 del Código Procesal Penal}

Con toda seguridad la fuente más fecunda de actuaciones judiciales capaces de crear peligro serio, cuando no ya franco atropello a la garantía de imparcialidad del tribunal, es la originada en los agudos y, en ocasiones, inusitados interrogatorios realizados por jueces de Tribunales de Juicio Oral en lo Penal al abrigo del inciso $4^{\circ}$ del artículo 329 del Código Procesal Penal. A menudo, ellos exhiben más oficio y talento escrutador que varios de los efebos y noveles intervinientes que litigan en su presencia.

En la causa RIT 58-2007 del Tribunal Oral en lo Penal de Puerto Montt seguida en contra de dos acusados como autores de dos delitos de robo con violencia, una de las juezas que integraba la sala sorprendió a los intervinientes al formular de conformidad con el inciso $4^{\circ}$ del artículo 329 del Código Procesal Penal la siguiente declaración: “...buenos días, hay un tema que me preocupa en atención a que los magistrados tienen derecho a hacer algunas preguntas, de acuerdo con la ley, para que se puedan aclarar algunas declaraciones que se han vertido en juicio cuando queda una situación de duda, sobre todo para resolver. Es comprensible siempre, que una persona que es víctima de un delito de cualquier naturaleza resulta alterada su psiquis y no es cómodo venir a declarar a un tribunal y venir a contar el mismo cuento $y$ menos delante de los agresores, ya,? (sic)..." 55 .

A propósito de este hecho sobreviniente ocurrido en pleno desarrollo de la audiencia, la defensa promovió en la siguiente sesión de juicio oral un incidente de inhabilidad argumentando que al tratar a los acusados como los agresores de la víctima que en ese momento se encontraba precisamente en frente de ellos vulneró la presunción de

${ }^{54}$ La decisión sobre la concurrencia de la inhabilidad no tiene relación con la calidad o naturaleza de los antecedentes de los que dispone el juez al momento de pronunciarse sobre la prisión preventiva. Así, la diferencia sobre "alcances y límites" entre la decisión sobre la prisión preventiva y la decisión sobre la absolución o condena invocada por el voto de minoría para desestimar la solicitud de inhabilitación de los jueces no constituye tampoco una razón relevante para considerar que no se produce la inhabilidad, pues para que esta se produzca basta que el juez anticipe el juicio independientemente de los alcances y límites del acto -judicial o no- en que este pronunciamiento tiene lugar. En efecto, ni el COT ni el CPP hacen distinción alguna sobre los alcances y límites, precisamente porque para la constitución de inhabilidad no es importante los diferentes efectos jurídicos que produzca la resolución del juez en la que anticipa su opinión, tampoco es importante el tipo de antecedentes que el juez toma en consideración para pronunciarse, lo único relevante es si el juez ha anticipado su veredicto.

${ }^{55}$ Considerando primero de la resolución de 17 de marzo de 2008 pronunciada por la Iltma. Corte de Apelaciones de Puerto Montt en la causa Rol Ingreso Corte N $^{\circ} 30-2008$. 
inocencia que amparaba a sus representados y su deber de imparcialidad, solicitando en concreto su recusación por haber manifestado su opinión sobre la cuestión pendiente de fallo con conocimiento de ella.

En una clara demostración de la incomodidad que este tipo de incidentes procesales provoca y de la confusión jurisdiccional que ocasiona su tramitación, el Tribunal Oral en lo Penal de Puerto Montt estimó que la facultad de la defensa para promover esa discusión se había extinguido, desde que, de acuerdo a la tramitación de los incidentes procesales civiles, supletoriamente aplicables al ámbito del juzgamiento penal, se debió alegar por la defensa de inmediato y en cuanto se tomó noticia de la actuación judicial, razón por la cual se rechazó la solicitud por haber caducado ${ }^{56}$ la oportunidad procesal de alegarlo válidamente.

Con posterioridad y una vez notificado de la condena de sus representados, la defensa interpuso para ante la Iltma. Corte de Apelaciones de Puerto Montt un recurso de nulidad del juicio y la sentencia, a efectos de ejercer los mecanismos represivos de la infracción de la garantía de imparcialidad del juzgador denunciada, habida consideración de que los mecanismos procesales de carácter precautorio consagrados en las causales de implicancia y recusación fueron desestimados por el propio Tribunal Oral en lo Penal bajo el argumento de la preclusión por caducidad del plazo.

El recurso de nulidad promovido por la defensa y fundado en infracciones de tratados internacionales sobre derechos humanos ${ }^{57}$ fue rechazado por la Iltma. Corte de Apelaciones de Puerto Montt. El tribunal de nulidad sostuvo en su resolución pronunciada en la causa Rol 30-2008 que la objeción a la falta de imparcialidad de uno de los jueces correspondía a una mera apreciación subjetiva del defensor, agregando que no se advertía cómo la pregunta de la magistrada influyó sustancialmente en lo dispositivo del fallo ${ }^{58}$-a pesar de que la jueza concurrió con su voto a la condena- para concluir afirmando que no estaba acreditada ninguna de las causales de inhabilitación del Código Orgánico de Tribunales, desde que esa consulta se dirigió a la primera testigo del juicio y sin que la jueza hubiera intervenido en la etapa de investigación, todo lo cual evidencia su desconocimiento de los antecedentes necesarios para dictar sentencia ${ }^{59}$.

\footnotetext{
56 Preclusión por no haber ejercido oportunamente un derecho.

${ }^{57}$ Artículo 8.1 de la Convención Americana de Derechos Humanos; Artículo 14.1 del Pacto Internacional de Derechos Civiles y Políticos; Artículo $5^{\circ}$ inciso segundo de la Constitución Política del Estado.

58 Resolución Causa Rol Ingreso Corte de Puerto Montt 30-2008, considerando noveno: "Que por lo demás, no se evidencia como tal afirmación de la Juez Sra. Santelices, haya podido influir sustancialmente en lo dispositivo del fallo, requisito de procedencia de la causal invocada que debe necesariamente concurrir, no basta con que exista una errada aplicación del derecho, cuestión esta última que por lo demás como se evidencia en el considerando anterior tampoco concurre".

59 Resolución Causa Rol Ingreso Corte de Puerto Montt 30-2008, considerando décimo: "Que por lo demás no concurrían en los hechos invocados las causales de inhabilidad del artículo 195 y 196 del Código Orgánico de Tribunales, invocadas por la defensa, tanto por que el hecho se produce durante el interrogatorio del primer testigo, de modo que no se da el requisito del conocimiento de los antecedentes necesarios para pronunciar sentencia, como tampoco la juez tuvo participación alguna en la investigación anterior al juicio, de modo que cualquier cuestión sobre procedencia o tramitación de la inhabilidad requerida, no influye en lo sustancial de la sentencia".
} 
Nada se dijo en la referida resolución sobre la eventual afectación de la dimensión objetiva de la garantía de imparcialidad del Tribunal, invocada por la defensa en su recurso de nulidad. Más bien, la Iltma. Corte de Apelaciones de Puerto Montt expresó una cierta indiferencia hacia ese aspecto del debido proceso, al considerar como una mera apreciación subjetiva de la defensa su cuestionamiento a la actuación indagatoria de uno de los jueces del Tribunal Oral en lo Penal que, en audiencia, llamó “agresores" a los acusados y, de paso, restringió a las antiguas normas del Código Orgánico de Tribunales el contenido del derecho al juez neutral, dejando de pronunciarse sobre el alcance más amplio reconocido en los Tratados Internacionales sobre Derechos Humanos.

2ci. Derecho de las partes a controlar y objetar preguntas de los jueces

Una sensibilidad distinta a la expuesta se advierte en el pronunciamiento de la Excma. Corte Suprema recaído en la causa rol 4164-0960, oportunidad en la que el máximo tribunal del país sostuvo lo siguiente: "en este entendido, cuando el tribunal decide de propia iniciativa llevar a cabo un improcedente interrogatorio, en el que no sólo excede los márgenes de lo legalmente permitido que son las preguntas aclaratorias, sino que lo que bace en realidad es suplir eventuales insuficiencias en la información lograda transmitir por el persecutor $y / 0$ de la defensa, de suerte que se entromete en el debido desarrollo del proceso, transgrede el principio de contradicción y, de paso, afecta su propia imparcialidad, y en algunos pasajes derechamente manifestando su dictamen sobre la cuestión pendiente, lo que no puede ser tolerado".

El mismo criterio se expresó en la causa Rol No 173-07 pronunciada a fines del año 2007 por la Ilustrísima Corte de Apelaciones de Copiapó que acogió un recurso de nulidad planteado por la defensa como remedio a los interrogatorios realizados a los testigos de cargo por los jueces del Tribunal Oral en lo Penal.

El fallo de ese Tribunal Superior reconoce el derecho de las partes a controlar y objetar las preguntas de los jueces, recordando el deber de pasividad que el tribunal debe mantener frente a las posiciones y la prueba de los litigantes, argumentando que frente a una controversia entre partes, el juzgador debe asumir una función de control y arbitraje, apegándose estrictamente al principio de imparcialidad ${ }^{61}$.

${ }^{60}$ Esta resolución de la Excma. Corte Suprema acogió un recurso de nulidad presentado por la defensora penal pública, doña Gilda Martínez Alfaro, quien por esta vía impugnó la falta de imparcialidad del Tribunal Oral en lo Penal de Chillán en la causa RIT No 33-2009.

${ }^{61}$ La resolución Rol 173-2007 de la Iltma. Corte de Apelaciones de Copiapó en su considerando quinto señala: "Por ello, la unanimidad de los tratadistas pregona, en lo que se refiere a las menguadas facultades probatorias del tribunal establecidas en el inciso cuarto del artículo 329 del Código Procesal Penal, mesura, prudencia e incluso prescindencia. Así, María Inés Horvitz Lennon y Julián López (Derecho Procesal Penal Chileno, Tomo II, pág. 295), Andrés Baytelman A. y Juan Enrique Vargas V. (La Función del Juez en el Juicio Oral, pág. 10 y siguientes), Cristian Maturana Miquel (Los Procedimientos en el Nuevo Sistema Procesal Penal, apuntes de clases, pág. 139 y 140), Rodrigo Cerda San Martín (Etapa Intermedia, Juicio Oral y Recursos, pág. 149). Por lo demás, a propósito de esta facultad, en la discusión legislativa en el Senado se dejó expresa constancia que las preguntas que formulen los miembros del tribunal a testigos y peritos: ¿no pueden referirse a bechos no comprendidos en su declaración, sino que tienen por objeto solamente aclarar pasajes oscuros o contradictorios de la misma? (Código Procesal Penal Anotado y Concordado, Emilio Pfeffer Urquiaga, pág. 496)”. 
El debate sobre este aspecto del litigio, sin embargo, no es pacífico ${ }^{62}$. El diario $E l$ Llanquibue de Puerto Montt en su edición de 18 de abril de 2007 en una nota titulada "Juez versus Defensor" informó de la molestia que en el magistrado que presidió la audiencia de juicio oral, seguida en contra de los acusados de robar y matar al sacerdote Benedicto Piccardo Olivos, provocó la objeción de la defensa penal pública a uno de sus interrogatorios. El incidente promovido por el abogado de la Defensoría fue replicado en tono áspero por el magistrado: "¿Acaso quiere responder usted la pregunta, señor Defensor?"63.

Como lo afirma el profesor Luis Díaz García, la facultad reconocida a los jueces del Tribunal Oral en lo Penal para formular preguntas a testigos y peritos destinadas a la aclaración de sus dichos no puede ejercerse para favorecer ni para obstaculizar la averiguación de la veracidad de los hechos imputados ni tampoco como medio destinado a despejar o preservar las dudas razonables acerca de la participación culpable de los acusados, porque aquello importa desentenderse del rol de juez y acudir en auxilio de los intereses de las partes ${ }^{64}$.

Coincidimos con el profesor Díaz García, quien postula que la solicitud de aclaración debe ejercerla el Tribunal Oral en lo Penal de modo restrictivo sólo cuando realmente una expresión del testigo o perito haya resultado verdaderamente incomprensible o ininteligible.

En consecuencia, quedan excluidas de ese ejercicio judicial las expresiones claramente imprecisas o contradictorias - pero comprensibles-, las que deberán ser capitalizadas o resistidas por los litigantes quienes a través de sus interrogatorios y contraexámenes las producen. Incorporadas a la audiencia como elementos de prueba quedan, en definitiva, a disposición de los jueces de fondo para que soberanamente se pronuncien en torno a su credibilidad y aporte a la decisión final ${ }^{65}$.

${ }^{62}$ En la causa RIT 34-2006 del Tribunal Oral en lo Penal de Puerto Montt la defensa de uno de los acusados de robo con homicidio objetó el interrogatorio realizado por una de las juezas de esa instancia y que a juicio de la defensa inequívocamente estaba destinado a establecer más allá de toda duda razonable que su representado era responsable penalmente de la muerte de la víctima. La magistrada sostuvo, en esa oportunidad, que las preguntas del Tribunal no son susceptibles de objeciones por las partes.

${ }^{63}$ Según la versión del diario El Llanquibue de 18 de abril de 2007, el Defensor respondió que pretendía hacer valer los derechos de sus defendidos, "y le estoy señalando al Tribunal que ese tema ya fue preguntado y si el Tribunal vuelve sobre el punto, corremos el riesgo de que se esté incorporando información a esta audiencia que puede ser utilizada en contra de los derechos de mi defendido", dijo.

${ }^{64}$ Díaz García, Luis Iván, "La facultad del tribunal oral en lo penal de aclarar dichos”, en Universidad Católica de Temuco, Chile. Seminario Reforma Procesal Penal, Santiago de Chile: Ed. ConoSur, 2001, pp. 221222.

${ }^{65}$ El profesor Díaz García en su artículo sobre la facultad del tribunal oral para aclarar dichos de testigos y peritos sostiene que si los jueces intervienen en el juicio oral se generan dos problemas. Por una parte, el tribunal habrá descendido de su posición preeminente, por sobre las partes y el debate. Y, por otra, los intervinientes quedarán en indefensión. 


\section{2d. Las actuaciones y prueba de oficio producidas por los jueces}

Una de las amenazas permanentes sobre la garantía de la imparcialidad del tribunal es aquella originada en las reminiscencias y tradiciones del antiguo proceso penal que llamaba a los jueces a erigirse en historiadores ocupados de la averiguación de la verdad y a los abogados a convertirse en auxiliares de esa monástica forma de administrar justicia. Un abogado integrante de la Ilustrísima Corte de Apelaciones de Puerto Montt ha llegado a considerar que los abogados de la Defensoría Penal Pública y los fiscales del Ministerio Público son colaboradores de la labor realizada por los Tribunales de Justicia ${ }^{66}$.

Así las cosas, no ha sido infrecuente en la experiencia forense acumulada en la Región de Los Lagos que se demande de los defensores penales públicos su necesaria contribución a la averiguación de la verdad histórica como vía de acceso a la justicia ${ }^{67}$, cuestionando incluso desde perspectivas de desempeño ético de la profesión las actuaciones de los abogados que mediante el ejercicio de los derechos procesales han resistido y cuestionado la labor indagatoria y de generación de pruebas de cargo desplegadas por algunos jueces ${ }^{68}$.

\footnotetext{
${ }^{66}$ Elocuente es el razonamiento plasmado en la causa Rol No 33-2007 de la Iltma. Corte de Apelaciones de Puerto Montt, donde uno de sus integrantes afirma en el motivo cuarto de su prevención: "Que sin perjuicio de lo resuelto anteriormente cabe tener presente que tanto el Ministerio Público, como la Defensoría Penal Pública, son organismos colaboradores de la justicia criminal, por lo que dentro de las funciones que les otorgan la Ley $N^{0} 19.640$, Orgánica Constitucional del Ministerio Público y la 19.718 que creó la Defensoría Penal Pública, respectivamente, tiene el deber de actuar de tal manera que permita a los Tribunales aplicar dicha justicia, evitando roces y conflictos innecesarios, que solamente conducen a desprestigiar la Reforma Procesal Penal".

${ }^{67}$ En la causa Rol No 86-2008 de la Ilustrísima Corte de Apelaciones de Puerto Montt, consta que frente a la solicitud de nulidad procesal planteada por la defensa de un acusado menor de edad, luego de enterarse que el recurso de apelación en contra del auto de apertura de juicio oral estaba siendo resuelto fuera de audiencia y mediante la lectura privada de la carpeta de investigación fiscal por parte de los Ministros de la Segunda Sala del Tribunal de Alzada, el representante del Ministerio Público en su escrito de solicitud de inadmisibilidad de la nulidad procesal, presentado el 4 de junio de 2008, dijo: "El estilo de la Fiscalía, y en particular de este abogado, al amparo del principio de objetividad que rige las actuaciones del Ministerio Público, ha sido siempre jugar limpio, aportando el máximo de antecedentes a los tribunales, a fin de que lo resuelto sea lo más cercano a lo justo. Por lo anterior, y sin perjuicio de lo antes expuesto, la única interpretación razonable que se le puede dar al incidente de nulidad procesal penal es que se pretende que sus SS. Ilustrísimas no tengan acceso a todos los antecedentes necesarios para resolver el recurso de apelación, lo cual, desde nuestra perspectiva, nos resulta censurable e incomprensible, sin embargo, teniendo presente los expuesto por el propio abogado de la defensa en la audiencia de la vista del recurso, parece ser que las ansias por lograr una absolución o una rebaja de pena superan con creces la necesaria contribución que todos los actores de este sistema debemos hacer para acercarnos a la verdad y en definitiva a la justicia".

${ }^{68}$ En la resolución de 23 de junio de 2008 en cuya virtud se rechazó el segundo incidente de nulidad procesal promovido por la defensa en la causa Rol Ingreso Corte N N $^{\circ} 6-2008$ a propósito de la revisión privada que los Ministros de la Segunda Sala de la Iltma. Corte de Apelaciones de Puerto Montt hicieron de la carpeta de investigación fiscal como expediente de resolución de un recurso de apelación presentado por el Ministerio Público, uno de sus Ministros Titulares por escrito previno que estuvo por representar a la defensa la inconveniencia que para la buena fe procesal tiene el que, el Defensor en su alegato haya hecho reiteradas referencias a piezas precisas de la carpeta de investigación, para luego incidentar, cuando la Corte precisamente fundado en su alegato debió traer la carpeta a la vista para un mejor acierto del fallo.
} 
Hay además reconocidos sectores de la doctrina, especialmente en el ámbito del proceso civil, que reconocen al juez poderes de iniciativa probatoria oficiosa que deben ser ejercidos de un modo imparcial, en el solo interés objetivo de la búsqueda y la determinación de la verdad histórica de los hechos controvertidos, a los fines de remover incertidumbres probatorias no superables para las partes, que de otro modo perjudicarían tal determinación ${ }^{69}$.

Sin embargo, tal como escribe Andrés Bordalí, para quienes sostenemos que un juez que dispone medios probatorios pierde su imparcialidad, el Código Procesal Penal nos da la razón, pues salvo el poder de los jueces para pedir a los testigos que aclaren sus dichos (art. 329 inciso $4^{\circ}$.), el tribunal carece de poderes probatorios oficiosos. "En esta parte el legislador chileno siguió la senda de un modelo de proceso penal adversarial o acusatorio puro, donde el poder de probar sólo corresponde a las partes"70.

En el denominado caso Díaz Flores en el que un adolescente de irreprochable conducta anterior fue acusado de cometer un robo con homicidio y un robo con violencia, ocurridos en la localidad de Carelmapu, Provincia de Llanquihue, la madrugada del 14 de septiembre de 2007, la garantía de imparcialidad del juzgador se convirtió en uno de los temas trascendentes en la resolución del caso.

En el primer juicio oral, José Luis Díaz Flores, hoy adulto, fue condenado por el Tribunal Oral en lo Penal de Puerto Montt que le impuso dos penas de 5 años y 1 día y 3 años y 1 día de régimen cerrado, por ambos delitos. La sentencia fue impugnada mediante recurso de nulidad presentado por la defensa penal pública para ante la Excma. Corte Suprema fundado en infracción de garantías constitucionales ${ }^{71}$.

La defensa sostuvo, en síntesis, que la condena del adolescente descansaba en la valoración de prueba pericial y testimonial que fue reincorporada al auto de apertura de juicio oral mediante una actuación impropia de la Iltma. Corte de Apelaciones de Puerto Montt que, mediante la solicitud de la carpeta de investigación fiscal, su revisión privada y estudio realizado al margen de la audiencia de vista del recurso de apelación, decidió reponer en el auto de apertura de juicio oral prueba de cargo excluida por ilicitud durante la preparación del juicio ${ }^{72}$, cuestión que afectó la garantía del procedimiento racional y justo e invalidando la sentencia condenatoria.

${ }^{69}$ Bordalí Salamanca, Andrés. Op. cit., en n. 26, p. 288.

${ }^{70}$ Bordalí Salamanca, Andrés. Op. cit., en n. 26, p. 289.

${ }^{71}$ Ingresado a la Secretaría de la Excma. Corte Suprema bajo el Rol No 4954-2008 con fecha 26 de agosto de ese año.

72 De esta actuación de los Ministros de la Iltma. Corte de Apelaciones de Puerto Montt la defensa reclamó mediante dos solicitudes de nulidad procesal de la vista del recurso de apelación presentado por el Ministerio Público en contra del auto de apertura de juicio oral y ambas fueron rechazadas mediante votación dividida. La actuación de los Ministros de la Iltma. Corte de Apelaciones de Puerto Montt originó además la presentación de una queja disciplinaria interpuesta ante la Excma. Corte Suprema, la que fue rechazada sin perjuicio de que cinco de sus Ministros estuvieron por pedir informe a los recurridos y el Ministro Sr. Sergio Muñoz para fundar su voto en contra de la inadmisibilidad de la queja tuvo, además presente, que la actuación impugnada excede las competencias propias de los magistrados en un procedimiento acusatorio adversarial. AD 940-2008 Excma. Corte Suprema. 
Este caso es ilustrativo, porque una sala de Corte de Apelaciones es un órgano colegiado al igual que el Tribunal Oral en lo Penal, y, sobre todo, porque las reglas generales de vista de los recursos en materia penal están informadas por el principio acusatorio ${ }^{73}$, aspecto reafirmado por los artículos 360 y 361 del Código Procesal Penal ${ }^{74}$, que expresamente impiden extender la vista del recurso a materias no expuestas por el recurrente y que de modo supletorio ordena aplicar las disposiciones del juicio oral, con lo cual las actuaciones judiciales realizadas al margen de esta regulación constituyen una amenaza seria, cuando no una manifiesta lesión a la garantía de imparcialidad del tribunal.

\section{2di. Solicitud fuera de audiencia de la carpeta de investigación fiscal}

La infracción a la garantía de imparcialidad fue confirmada por la Excma. Corte Suprema en la causa Rol 4954 de 2008. Al anular el juicio oral y las dos penas de régimen cerrado impuestas al condenado, el máximo tribunal del país sostuvo en su considerando cuarto que la alegación que el recurrente ha formulado por la causal de la letra a) del artículo 373 del Código Procesal Penal, está basada única y exclusivamente en el hecho de haberse realizado una actuación ilegal por la Corte de Apelaciones de Puerto Montt durante el conocimiento y resolución de la apelación interpuesta por el Ministerio Público contra la resolución del Juzgado de Garantía que había excluido cierta prueba.

Esa actuación ilegal consistió en haberse solicitado por la misma Corte fuera de audiencia la carpeta de investigación, lo que en concepto del recurrente vulneró las garantías constitucionales del acusado referidas a su derecho a un debido proceso, específicamente en cuanto dice relación con la imparcialidad del tribunal y su derecho a defensa ${ }^{75}$.

${ }^{73}$ El artículo 358 del Código Procesal Penal establece que la incomparecencia del recurrente origina el abandono del recurso; suprime el trámite de la relación; es el recurrente quien expone su recurso y luego se ofrece la palabra a los recurridos y las dudas del tribunal sólo pueden aclararse mediante preguntas dirigidas a los representantes de las partes.

${ }^{74}$ Artículo 361 del Código Procesal Penal: Aplicación Supletoria. Los recursos se regirán por las normas de este libro. Supletoriamente, serán aplicables las reglas del Título III del Libro Segundo de este Código (juicio oral).

75 Considerando noveno de la resolución 4954-2008 de la Excma. Corte Suprema: Que es necesario recordar en esta parte que el artículo 361, ubicado en el Título I de las disposiciones generales de los recursos, prescribe que éstos se rigen por las normas de ese libro y en forma supletoria, lo serán por las del Título III del Libro Segundo de ese código. El Libro II, Título III, es el que señala las normas que rigen el juicio oral, de modo que no corresponde hacer aplicación supletoria de las prescripciones del Código de Procedimiento Civil. En este sentido, la revisión de cada una de las disposiciones del señalado título permiten concluir sin lugar a dudas que la iniciativa probatoria nunca es del juez, sino siempre de las partes, quienes tienen completa libertad para demostrar los hechos y circunstancias pertinentes para la adecuada solución del caso sometido a enjuiciamiento.

Por último, el artículo 360, relativo a las decisiones de los recursos, circunscribe el pronunciamiento del tribunal exclusivamente a las solicitudes formuladas por los recurrentes, quedándole vedado extender el efecto de su decisión a cuestiones no planteadas por ellos o más allá de los límites de lo solicitado.

De todo lo expresado, es posible extraer como conclusión, que la Corte de Apelaciones cuando conoce del recurso deducido por el Ministerio Público contra el auto de apertura por la exclusión de pruebas determinadas por el Juez de Garantía, debe limitarse a escuchar los hechos y argumentos que las partes le exponen y los antecedentes que ya obren en la carpeta que ha recibido. Cualquier duda que se le presente puede salvarla de inmediato, ante las mismas partes, por cuanto 
Por último, el máximo tribunal del país sostuvo que cuando en materia penal el juzgador decide de propia iniciativa disponer una determinada diligencia, lo que hace en realidad es suplir la insuficiente exposición del persecutor y/o de la defensa, de modo que se entromete en el debido desarrollo del proceso quebrando el principio de contradicción y, de paso, afectando su propia imparcialidad. La Corte agregó: Que como se ha analizado hasta aquí, aparece evidente que la Corte de Apelaciones de Puerto Montt, al decidir solicitar la carpeta de investigación del Ministerio Público, para el mejor acierto de la apelación planteada, incurrió en una violación de las garantías constitucionales que aseguran al imputado el derecho a defensa y su debido proceso. El empleo de esa carpeta como aporte de conocimiento faltante o necesario de los datos de la causa, para resolver la apelación pendiente, queda en evidencia de la sola lectura del fallo pronunciado con motivo de ese arbitrio procesal, y donde es posible advertir, por ejemplo en su motivo tercero, que la Corte decidió con el mérito de los antecedentes de la carpeta de investigación de cuyo contexto tuvo por establecidos ciertos hechos ${ }^{76}$.

\section{2dii. Revisión de oficio del extracto de filiación del imputado}

Este fallo de la Excma. Corte Suprema tiene un precedente en el mismo sentido, pronunciado en la causa Rol No 4989-05 de diciembre de 2005 y ha sido mantenido con posterioridad en la causa Rol 7824-08 de 27 de enero de 2009 a propósito de la aceptación de un recurso de nulidad presentado por el defensor local de Ancud, quien reprimió exitosamente, vía recurso de nulidad, la infracción a la garantía de imparcialidad

ello tiene el objeto que lo dicho por una de ellas pueda ser siempre conocido por la otra y controvertido o complementado, en su caso. Esta es la forma en que, actualmente, se conoce la apelación de un proceso penal. El tribunal no pide pruebas, no dispone oficiosamente la práctica de ninguna diligencia probatoria, ni para mejor resolver, puesto que la naturaleza propia de éstas cual sería la de las contempladas en el artículo 159 del Código de Procedimiento Civil-es precisamente agregar antecedentes probatorios o datos que no habian quedado suficientemente satisfechos.

En la reforma penal, las dudas del tribunal deben ser satisfechas por las partes, en este proceso, fiscal y/o querellante en su caso, y defensor. Ellos deben poner en conocimiento del tribunal todos sus argumentos y plantear los hechos de forma acabada y suficiente para que el tribunal quede bien informado sobre aquello que ba sido sometido a su conocimiento, de modo que de subsistir cualquier duda o de haber verificado alguna inexactitud, el tribunal pregunta a las mismas partes, en la audiencia, sobre lo que le ha resultado oscuro o desconocido.

Esta forma de llevar adelante la audiencia y la vista de las causas ante las Cortes de Apelaciones, es una manifestación del principio contradictorio que rige en el nuevo sistema penal y que constituye un elemento del derecho a defensa $y$, además, del debido proceso, por cuanto la imparcialidad del tribunal se asegura y garantiza a través del veto a su iniciativa probatoria. Es este último, también, el motivo por el cual se ha asegurado a los intervinientes el derecho a ejercer sus facultades con tiempo y con los medios adecuados. El Ministerio Público dispone de un plazo para investigar y para reunir todos los elementos necesarios para establecer el hecho ilícito, así como la participación del delincuente e incluso, para determinar la existencia de circunstancias especiales que puedan atenuar, modificar o eximir de responsabilidad a este último. Por su parte, la defensa tiene garantizado el tiempo y los medios, al igual que el Ministerio Público y tiene también el derecho para acceder a todos los medios de prueba que se han reunido en la investigación, con el preciso objeto de controvertirlos, refutarlos, o simplemente explicarlos. Esta defensa que ha sido circunscrita en este procedimiento a los abogados habilitados, para garantizar su experiencia, debe ser eficaz y técnica, razones todas por las cuales no se ve cuál podría ser la necesidad de dotar al tribunal, además, de facultades probatorias o para mejor acierto de lo que se somete a su conocimiento.

${ }^{76}$ Considerando décimo de la resolución pronunciada por la Excma. Corte Suprema el pasado 12 de noviembre de 2008 en la causa Rol No 4954-2008. 
del tribunal luego de la denegación a su representado del derecho a cumplir en libertad su condena, sobre la base de una anotación prontuarial pretérita registrada en su extracto de filiación que no fue invocada por el fiscal de la causa y que de oficio fue considerada por el juez para ordenar el cumplimiento efectivo de la pena de 61 días de presidio menor en su grado mínimo, impuesta al condenado como autor del delito de manejo en estado de ebriedad.

\section{2e. Los cambios intempestivos en la integración del Tribunal Oral en lo Penal}

Probablemente el caso Piccardo es uno de los juicios tramitados bajo el actual proceso penal que más discusión ha generado en torno a la garantía de imparcialidad objetiva del Tribunal Oral en lo Penal, precisamente porque el hecho ocurre en una sociedad tradicional, de estrechas relaciones sociales, como la de Puerto Montt, con una víctima que era un reconocido sacerdote católico, rector del liceo público donde se formaron varios de los miembros de sus primeras generaciones de profesionales e hijo ilustre de la ciudad, y donde atendidas esas circunstancias las apariencias de indiferencia judicial eran muy difíciles de garantizar, especialmente entre algunos de los jueces del Tribunal Oral en lo Penal de Puerto Montt de dilatada historia de vida en la comuna ${ }^{77}$, con acusados que desde su detención y frente a la marea de condenas públicas previas al juicio siempre temieron enfrentar un juicio parcial.

Ese recelo se incrementó cuando ya notificada la fecha del juicio oral, programado para el 16 de abril de 2007 y comunicada la integración del Tribunal Oral, sorpresivamente y sobre la base de razones de mejor servicio, se informó una nueva resolución que cambió la composición de los jueces que conocerían de la acusación fiscal. Ese hecho fue informado el 26 de marzo de ese mismo año por la radio Bío-Bío de Puerto Montt como una señal de endurecimiento de la instancia y su difusión no hizo más que incrementar los temores de parcialidad del juzgamiento entre los acusados.

Ya iniciado el juicio, en la edición del 17 de abril de 2007 se publicó en el diario La Tercera una nota de prensa, donde el juez originalmente designado para conocer del juicio y luego liberado de esa responsabilidad informaba que otro de los magistrados le pidió integrar la sala, porque debido a razones personales necesitaba permanecer en Puerto Montt durante esa semana, cuestión que al menos develaba la inobservancia de un procedimiento objetivo, capaz de garantizar el derecho al juez natural como manifestación de imparcialidad objetiva.

${ }^{77}$ El abogado de la procuraduría fiscal de Concepción del Consejo de Defensa del Estado, Remberto Valdés Hueche, aborda el tema de la garantía de la imparcialidad del juzgador y señala, por ejemplo, que en la experiencia norteamericana ha sido posible trasladar de ciudad los juicios penales, precisamente, para contar con un jurado que no haya estado intensamente expuesto a la información periodística ni a la conmoción causada por el hecho, precisamente, como medida de protección de la garantía de imparcialidad frente a los riesgos de prejuicio creado por casos de connotación pública. Valdés Hueche, Remberto, "El proceso. La imparcialidad. Sistema inquisitivo y acusatorio. La concepción unitaria del proceso. La Constitución Política y los tratados de derechos humanos", en Revista del Consejo de Defensa del Estado, Chile, N 12 , diciembre, 2004. 
El punto, expuesto por la defensa en su recurso de nulidad, fue categóricamente desvirtuado por la Excma. Corte Suprema en su resolución 2426-2007 de doce de julio de ese año, al indicar en su considerando décimo séptimo que tampoco se dará valor para los fines que se persiguen a la documental consistente en la comunicación de la integración del tribunal encargado de conocer del juicio oral y la posterior sustitución del magistrado José Bustos Valenzuela por doña Patricia Miranda Alvarado pues, a este respecto, no se ha rendido ninguna probanza que advierta de ello proceder ajeno a la normal organización de la labor del tribunal ${ }^{78}$. No se menciona en el recurso ninguna causal que configure inhabilidad de la indicada juez para el ejercicio de su labor, por lo que carece de todo sustento esta alegación, más bien constituye una suposición proscrita en un recurso de esta naturaleza.

2ei. La voluntad de que nadie inhabilite al juez

Probablemente este fallo de la Excma. Corte Suprema reafirma la opinión del abogado de la Procuraduría Fiscal de Concepción del Consejo de Defensa del Estado, Remberto Valdés Hueche, quien sostiene que las causales de inhabilidad de un juez penal contenidas en los artículos 195 y 196 del Código Orgánico de Tribunales y ajustadas a la Reforma Procesal Penal por la Ley N 19.708 de enero de 2001, son insuficientes no sólo porque abordan aspectos de pura incompetencia subjetiva, sino porque existen numerosas situaciones que escapan a su numeración taxativa y excluyente: "El legislador escribió bajo la idea de un sistema inquisitivo tanto en lo civil como en lo penal y desea que nadie inhabilite a su juez; y la propia concepción chilena acerca de nuestros jueces quiere ver en ellos a seres superdotados, ajenos al mundo de todos los justiciables ${ }^{79}$.

A lo anterior, se suma el hecho de que los motivos absolutos de nulidad del Código Procesal Penal previstos en su artículo 374 no hacen referencia a la garantía de imparcialidad del tribunal, sino sólo a la sentencia pronunciada por juez legalmente implicado o recusado, con lo cual el cambio intempestivo de integración de la sala del Tribunal Oral en lo Penal impide presumir de derecho la nulidad del juicio y la sentencia, desde que no es causal de inhabilitación de acuerdo al Código Orgánico de Tribunales.

Esa circunstancia de alteración del Tribunal por necesidades estrictamente personales y sobrevinientes de sus miembros o de simple mejor servicio, como se justificó en el caso Piccardo, son difíciles de abordar como motivo genérico de un recurso de nulidad por infracción a la garantía de imparcialidad del tribunal, porque en ese ámbito de la

${ }^{78}$ En esta materia, la construcción de una eventual causal de nulidad exige al recurrente revisar el Manual de Procedimiento para los Tribunales de Juicio Oral de la Reforma Procesal Penal, el que en cumplimiento de lo dispuesto en el artículo 17 del Código Orgánico de Tribunales establece un procedimiento objetivo y general de distribución de causas que regula no sólo el sorteo de las salas, sino también su integración a través de regulaciones preestablecidas, que proscriben los riesgos de voluntarismo en la materia.

79 Valdés Hueche, Remberto, "El proceso. La imparcialidad. Sistema inquisitivo y acusatorio. La concepción unitaria del proceso. La Constitución Política y los tratados de derechos humanos”, en Revista del Consejo de Defensa del Estado, Chile, No 12, diciembre, 2004, p. 2 
impugnación no opera la presunción de derecho de la trascendencia del vicio reclamado, como sí ocurre con los motivos absolutos de nulidad. En este escenario, resulta en extremo difícil lograr la nulidad de la sentencia. Tal como lo sostuvo la Excma. Corte Suprema en este caso, el recurso de la defensa se rechazó al no indicar cómo se infringió el procedimiento de organización del tribunal, a lo que cabe agregar que en su solicitud de invalidación el recurrente no hizo referencia a la sustancialidad de la infracción reclamada, ni a su influencia en lo dispositivo del fallo, ni tampoco a su debida preparación, todo lo cual evidencia las rémoras cuyo sorteo exige nuestra legislación antes de reprimir la afectación de la garantía del juez imparcial en la dimensión objetiva que le ha reconocido el derecho internacional.

\section{2f. Defensa social y exasperación punitiva}

Ha habido casos en que los juzgadores de oficio han asumido una suerte de defensa social, imponiendo contra ley o derechamente sin fundamentación penas superiores a las solicitadas por los órganos a quienes se ha confiado el ejercicio de la acción penal ${ }^{80}$. En el caso López Alvarado, correspondiente a la causa RIT 35-2007 del Tribunal Oral en lo Penal de Puerto Montt, tanto el Ministerio Público como el querellante particular pidieron en sus respectivas acusaciones que al imputado se le impusiera una pena única de 15 años y 1 día de presidio mayor en grado medio como autor de los delitos de abuso sexual infantil y violación impropia.

Si bien el fiscal de la causa y el abogado de la víctima sostuvieron que tratándose de delitos de la misma especie cabía aplicar el artículo 351 del Código Procesal Penal y, sobre esa base normativa, se debía imponer una pena única de 15 años y 1 día de presidio mayor en su grado medio, por unanimidad los jueces que integraron la sala del Tribunal Oral en lo Penal de Puerto Montt se apartaron de las solicitudes de las partes. De oficio decidieron dejar de aplicar esa norma y, en cambio, optaron por la acumulación material de penas del artículo 74 del Código Penal, para de ese modo imponer al condenado una pena superior a través de la suma de 12 años de presidio, como autor de violación impropia y 7 siete años de privación de libertad, como autor de abuso sexual infantil, desconociendo así la obligación de aplicar la norma más favorable al justiciable

${ }^{80}$ En la causa Rol 34-2004 del Tribunal Oral en lo Penal de Puerto Montt, dos de los tres jueces subieron la pena solicitada por el fiscal de la causa en tres años de privación de libertad, imponiéndola en definitiva en 8 años de presidio mayor. El voto de minoría expresamente dejó constancia por escrito de las razones por las cuales se opuso a la voluntad de los jueces de mayoría y a la exasperación punitiva que emprendieron de oficio: "Que a la consagración a nivel de garantía fundamental ha que se hace referencia, basados en los principios de lesividad y proporcionalidad, se debe anotar también, que la historia del derecho penal y de la pena, puede ser leída como la historia de una larga lucha contra la venganza, correspondiendo la última etapa de esa bistoria, al momento en que se produce la disociación entre el Juez y la parte ofendida, de modo que la justicia privada, los duelos, los linchamientos, las ejecuciones sumarias, no fueron solo dejadas sin tutela sino además probibidas, naciendo en ese preciso momento el Derecho Penal, convirtiendo la relación bilateral del conflicto, ofendidolofensor, en una trilateral. Por esto es, que cada vez, que un juez aparece animado por sentimientos de defensa social, quiere decir que el derecho penal, regresa a un estado salvaje, anterior al nacimiento de la civilización (Luigi Ferrajoli en op. cit., pág. 38)”. 
en casos de reiteración de delitos de la misma especial, como expresamente lo ordena el inciso tercero del artículo 351 del Código Procesal Penal.

Especialmente reveladora de la falta de imparcialidad del tribunal resultó la opinión de una de las juezas del Tribunal Oral en lo Penal de Puerto Montt. Expresamente previno en la sentencia condenatoria que la pena debiera ser ya no de 15 años y 1 día como lo solicitó la parte acusadora en ejercicio de su pretensión punitiva, ni tampoco de 19 años, derivados de la acumulación material de una pena de 12 años y otra de 7 años, acordada por la mayoría de los jueces de la sala, sino una pena todavía mayor, de 25 años de privación de libertad para que, tal como lo sostuvo en el fallo, le dé tiempo al condenado de reconsiderar su desprecio hacia la comunidad, su mujer y sus hijas e hijos.

La defensa del condenado, en esta oportunidad, no impugnó la infracción a la garantía de imparcialidad del tribunal a través de su recurso de nulidad, sino la errónea aplicación del derecho que importó aplicar una pena mayor a la que legalmente procedía, petición que de modo unánime fue rechazada por la Ilustrísima Corte de Apelaciones de Puerto Montt que, en la causa Rol Ingreso de Corte N $^{\circ} 254-2007$, sostuvo que, en este escenario, resuelto por los jueces del fondo el ilícito investigado y el tratamiento legal, es procedente precisar que la cuantía de la pena a fijar corresponde a una facultad privativa de los jueces, sobre la cual el tribunal de alzada queda absolutamente excluido ${ }^{81}$.

En la causa RIT N 20-2009, el Tribunal Oral en lo Penal de Puerto Montt al resolver una acusación por un delito de violación impropia, nuevamente impuso al acusado una pena dos años superior al mínimo del presidio mayor en su grado medio solicitado por el fiscal del Ministerio Público y la parte querellante. Esta decisión fue impugnada para ante la Excma. Corte Suprema por infracción a la garantía de imparcialidad del tribunal, desde que la sentencia no entregó razones para apartarse de la pretensión punitiva de los acusadores y, por el contrario, reconoció al condenado la atenuante de cooperación sustancial al esclarecimiento de los hechos, invocada por la defensa.

Sin embargo, sobre esta materia la Excma. Corte Suprema al rechazar el recurso de nulidad, al parecer flexibilizó la regla de pasividad judicial, expresada en diversos fallos anteriores $^{82}$ y sostuvo en la causa Rol No 3909-09 que la fase de determinación judicial de la pena, junto a la apreciación de la prueba y la aplicación del precepto jurídico penal a los hechos probados, constituye una tercera función autónoma del juez penal y representa la culminación de su actividad decisoria.

\section{2g. Otros casos de potencial afectación de la garantía de imparcialidad por el Tribunal de Juicio Oral en lo Penal}

Ya decíamos que es imposible subordinar a un catálogo cerrado los posibles casos de afectación de la garantía de imparcialidad por parte de Tribunales de Juicio Oral en

${ }^{81}$ De esta resolución de la Iltma. Corte de Apelaciones de Puerto Montt, la defensa del condenado recurrió.

${ }^{82}$ El deber de pasividad del tribunal en materia procesal penal aparece expresamente reconocido por la Excma. Corte Suprema, entre otras, en las causas Rol Nos. 4889-05; 4954-08; 7824-08 y 4164-09. 
lo Penal, llamados a conocer y resolver los hechos que revisten caracteres de delito con apego estricto al principio acusatorio que informa el actual proceso penal.

Con seguridad los años de futura práctica forense de los operadores de nuestro proceso penal enriquecerán el análisis casuístico, pero, por lo pronto, nos interesa esbozar al menos algunas prácticas judiciales capaces de lesionar la garantía de imparcialidad del juzgador y que consideramos susceptibles de censura a través del recurso de nulidad.

De acuerdo al artículo 343 del Código Procesal Penal, el pronunciamiento sobre circunstancias modificatorias de responsabilidad penal que integran el hecho punible debe estar contenido en la decisión sobre absolución y condena que se comunica a las partes inmediatamente de concluida la deliberación privada de los jueces, de tal suerte que, si el Tribunal abre debate sobre atenuantes o agravantes contenidas en los hechos sometidos a juicio con posterioridad al pronunciamiento del veredicto, su actuación rompe la imparcialidad, desde que ese aspecto imperativamente debió resolverse en el veredicto condenatorio, quedando clausurada la posibilidad de abrir debates posteriores sobre el punto y, peor aún, modificar la extensión de la pena sobre la valoración que de ellas se pretenda realizar en la redacción de la sentencia, a menos que se sacrifique la garantía que asegura al justiciable la pasividad e indiferencia del juzgador frente a los intereses parciales de los litigantes.

\section{2gi. Tribunal Oral en lo Penal que antes condenó a un coimputado}

De acuerdo al Código Procesal Penal, el Tribunal de Juicio Oral en lo Penal dictará sobreseimiento temporal cuando el acusado no hubiere comparecido a la audiencia y hubiere sido declarado rebelde ${ }^{83}$. Es posible, entonces, que surja un conflicto de imparcialidad judicial en estos casos. En efecto, así ocurriría, por ejemplo, cuando el imputado rebelde es detenido y puesto a disposición del tribunal con posterioridad a la dictación del veredicto de condena del coacusado y con el evidente propósito de conocer y someter a prueba en esta segunda oportunidad los cargos ahora dirigidos en su contra.

El punto es del mayor interés porque, nuevamente, las causales de implicancia y recusación no abordan este problema de serias sospechas de prejuicio y se muestran insuficientes para garantizar un debido proceso, desde que, por ejemplo, se podría desestimar la solicitud de inhabilitación del tribunal bajo el argumento de que respecto del rebelde los jueces no han emitido dictamen alguno, ya que la condena se impuso a una persona distinta.

En consecuencia, atendida nuestra tradición jurisprudencial en la materia es muy probable que los mecanismos preventivos de infracción de la garantía de imparcialidad no produzcan efectos en la causa, por inexistencia de causal legal de inhabilitación preexistente y renuencia a la vinculación directa de los tratados internacionales sobre derechos humanos. Antes del juicio, entonces, la decisión sobre este punto quedaría entregada al criterio personal de los jueces que, en virtud al temor de prejuicio expresado por la

\footnotetext{
${ }^{83}$ Artículo 252 inciso final del Código Procesal Penal.
} 
defensa del acusado, podrían inhabilitarse de oficio en los términos del artículo 76 del Código Procesal Penal, sin perjuicio de la posibilidad de intentar un incierto recurso de nulidad ex post para el evento de la condena.

Ilustrativo sobre este punto resulta lo resuelto por la Corte Suprema de la Nación Argentina ${ }^{84}$ en la causa $\mathrm{N}^{\circ} 2370$ de 8 de abril de $2008^{85}$, oportunidad en la que se acogió un recurso extraordinario de recusación de los miembros de la sala que condenó al coacusado que fue juzgado en una primera audiencia a la que no concurrió el recurrente, quien fue detenido con posterioridad. El máximo tribunal trasandino acoge la acción preventiva, argumentando lo siguiente: "que se trata de circunstancias especiales que inciden en menoscabo del servicio de justicia y requieren amparo en la oportunidad en que emerge y se alega el concreto caso constitucional (Fallos: 311:266; 314:107, entre otros), las que deben ser valoradas para evitar que la garantía del debido proceso - en la cual la imparcialidad del juzgador es condición necesaria-pueda verse lesionada con el mantenimiento de condiciones adversas para el correcto ejercicio del derecho de defensa. Además, esta es la única oportunidad para analizar el planteo, puesto que frente a una eventual decisión final condenatoria el tratamiento posterior del agravio y la revisión de lo actuado resultarian tardios e implicarian un desgaste jurisdiccional".

La Corte Suprema de la Nación Argentina reconoció la necesidad de que los jueces sean imparciales desde un punto de vista objetivo, agregando que deben ofrecer garantías suficientes para que no haya duda legítima al respecto, agregando que bajo ese análisis objetivo se debe determinar si, aparte del comportamiento personal, hay hechos averiguables que podrían suscitar dudas respecto de su imparcialidad.

2gii. El Tribunal que se desentiende de lo alegado por las partes

Coincidimos también con el profesor Rodrigo Valenzuela Cori cuando postula que si bien no existe un juez objetivo sin una historia personal y ajeno a las influencias culturales, es posible aspirar a un juzgador imparcial. Sería imparcial aquél que no desatiende lo alegado por ninguna de las partes para decidir desde una postura propia, personal y por encima del contradictorio, sino que es verdaderamente desinteresado el juez que resuelve escuchando, considerando e incorporando a su proceso deliberativo todas las posturas contrapuestas que chocan ${ }^{86}$.

Su conclusión la apoya en la máxima del pensamiento ampliado de Kant que para acceder a un punto de vista universal exige desligarse de las condiciones personales subjetivas de juicio, para adoptar el punto de vista de los otros. Y agrega: "Como se ve, ese punto de vista universal no se logra desde un punto de vista superior situado en las alturas, sino colocándose en el punto de vista de los otros. Una carta escrita por Kant en 1770 complementa

\footnotetext{
${ }^{84}$ Sala integrada por los magistrados Elena Highton de Nolasco, Carlos Fayt, Enrique Petracchi, Juan Carlos Maqueda, Raúl Zaffaroni y Carmen Argibay.

85 http://www.derechopenalonline.com/derecho.php?id=31,528,0,0,1,0

${ }^{86}$ Valenzuela Cori, Rodrigo, Conflicto y Humanidades. Un Ensayos sobre Argumentación Jurídica, Editorial Jurídica de Chile, Santiago, primera edición, octubre 2004, pp. 156, 157 y 158
} 
su idea de la imparcialidad. Dice: Tú sabes que yo no enfrento las objeciones razonables con el sólo ánimo de refutarlas, sino que al pensarlas siempre las entrecejo con mis juicios, dándoles la oportunidad de revertir mis más queridas creencias. Tengo confianza en que viendo mis juicios de este modo imparcialmente desde el punto de vista de los otros, una tercera perspectiva que mejore mi entendimiento anterior se pueda obtener. Hannah Arendt comenta este texto como sigue: Como ustedes ven, la imparcialidad se obtiene tomando en cuenta los puntos de vista de otros; la imparcialidad no es la consecuencia de un punto de vista más alto que resuelva la disputa manteniéndose por encima de la gresca" 87 .

En consecuencia, el actuar imparcial exige que la decisión descanse sobre los argumentos invocados por las partes en apoyo de sus pretensiones, sea para informar lo dispositivo del fallo o, como contrapartida, para ser razonadamente desestimado. Una sentencia que omite un pronunciamiento de fondo sobre las alegaciones de los intervinientes infringe la garantía del juez imparcial.

Por supuesto, esa inactividad del sentenciador deberá recaer sobre los aspectos de relevancia penal expuestos por los litigantes, desde que en materia de garantías constitucionales es necesario acreditar el carácter sustantivo y trascendente de la infracción reclamada $^{88}$, desde que el silencio judicial recaído en aspectos meramente adjetivos o accidentales del debate producido en audiencia, carece de la envergadura suficiente para invalidar lo resuelto ${ }^{89}$.

${ }^{87}$ Hannah Arendt, Kant Lectures, conferencias dictadas en la New York School for Social Research en Otoño de 1970, citada por Rodrigo Valenzuela Cori en op. cit., página 158.

${ }^{88}$ Desde luego si la infracción se pretende reclamar al margen de los motivos absolutos de nulidad del artículo 374 del Código Procesal Penal es menester que una causal genérica de nulidad acredite la sustancialidad de la infracción a los derechos o garantías asegurados por la Constitución o los Tratados Internacionales ratificados por Chile y que se encuentren vigentes, como lo exige el artículo 373 a) del Código Procesal Penal y debe tratarse además de un defecto esencial, porque tal como prescribe el artículo 375 del Código Procesal Penal no causan nulidad los errores de la sentencia recurrida que no influyeren en su parte dispositiva.

${ }^{89}$ En la causa Rol N $3193-08$ de diecinueve de agosto de 2008 la Excma. Corte Suprema sostuvo que si consideramos que la pretensión punitiva ha de concretarse, en cada caso, en la imputación de uno o más hechos que, con arreglo a la ley penal sustantiva configuran un determinado delito, serán hechos relevantes o pertinentes aquellos que acrediten o excluyen la presencia de los componentes del delito, la participación culpable del hechor y las circunstancias modificatorias de su responsabilidad criminal, comprendidas en la acusación.

El mismo criterio había sido ya afirmado por la Excma. Corte Suprema en la causa Rol No 3297-05 de 23 de septiembre de 2005, oportunidad en la que afirma: Esta idea de la relevancia la encontramos, bajo la denominación sinónima de pertinencia, en el artículo 276 del Código Procesal Penal cuando se refiere a las pruebas que fueren manifiestamente impertinentes y a la reducción del número de testigos o documentos cuando se deseare comprobar circunstancias que no guarden pertinencia sustancial con la materia sometida al conocimiento del tribunal del juicio oral. Que esta noción adquiere interés si se repara en que las narraciones de los hechos de la acusación y de la defensa en el contexto del debate contradictorio aparecen plagadas de circunstancias accidentales carentes de mayor importancia para la resolución de la controversia y cuya demostración tiende muchas veces al entorpecimiento de los objetivos perseguidos por el proceso penal. 
2giii. Advertencia judicial sobre la recalificación jurídica orientada a exasperar la pena

Por último, en la causa RIT 40-2008 del Tribunal Oral en lo Penal de Puerto Montt se advirtió un caso susceptible de infringir la garantía de imparcialidad del juzgador, luego que el juez presidente de la sala, ante una acusación por dos abusos sexuales infantiles, y, recién iniciado el juicio, advirtiera a la defensa que en opinión de dos de los tres jueces que integraban el tribunal los hechos imputados no correspondían a los delitos atribuidos por el Ministerio Público a su representado, sino a otros notablemente más graves como lo eran las sustracciones calificadas de menores de edad, hechos a los cuales la ley asigna en abstracto una penalidad que parte en los diez años y un día de presidio mayor en su grado medio.

En esa oportunidad, la defensa penal pública representó en la audiencia, específicamente durante la sesión de los alegatos de clausura, la afectación de la garantía de la imparcialidad del tribunal sin éxito, puesto que se condenó al acusado por los delitos imputados por el fiscal de la causa. El artículo 341 del Código Procesal Penal que permite al juzgador calificar el hecho imputado de manera distinta de aquélla contenida en la acusación fiscal, es una facultad regulada en el párrafo 10 del libro II Título III de ese cuerpo legal, razón por la cual no es posible ejercerla al inicio del juicio, sino luego de la deliberación privada y siempre que se garantice el debate de partes sobre esa nueva apreciación jurídica.

Anunciar nuevas calificaciones jurídicas sin haber conocido ni siquiera la prueba producida en el juicio, aparece como una actuación judicial sospechosa de parcialidad, entre otras cosas, porque no tiene más apoyo que los simples prejuicios de los juzgadores, surgidos al abrigo de una lectura precipitada de la acusación fiscal y huérfana de las alegaciones de las partes.

Lo expuesto no puede significar que el derecho aplicable y que decide un caso permanezca ajeno al contradictorio y a la dialéctica argumentativa de los litigantes, a pretexto de la primacía del viejo principio iura novit curia. Andrea Meroi sostiene que es inadmisible que los litigantes sean sorprendidos por una decisión que se apoye fundamentalmente en una visión jurídica de la que no estén en conocimiento. El tribunal debe, por lo tanto, dar conocimiento previo de qué dirección o derecho subjetivo corre peligro $^{90}$, a lo que nosotros agregamos que de cara a la garantía de imparcialidad del juzgador esa prevención debe efectuarse en el momento procesal oportuno. Esto es, luego de la deliberación y de un modo que permita a las partes debatir sobre el sobreviniente derecho decisorio litis, tal como lo prescribe el inciso tercero del artículo 341 del Código Procesal Penal.

De lo contrario, una advertencia judicial prematura y precipitada puede ser leída por el acusado o su defensa técnica como una amenaza o amedrentamiento capaz de

${ }^{90}$ Meroi, Andrea A., "Iura novit curia y decisión imparcial", en Ius et Praxis, año 13, No 2, Universidad de Talca, Chile, p. 386. 
comprometer la faz objetiva de la garantía en análisis, especialmente cuando el Tribunal anticipa una calificación jurídica apta para provocar una exasperación punitiva que va más allá de lo solicitado por el fiscal en su pretensión punitiva.

Otras situaciones como, por ejemplo, la posibilidad del Tribunal Oral en lo Penal de tener por acreditados hechos que van más allá de los imputados en la acusación fiscal, si bien lesionan la garantía de imparcialidad del tribunal, al igual que impedir al defensor ejercer las facultades que la ley le otorga, no serán tratadas en el presente artículo, porque si bien podrían servir de base a una causal genérica de nulidad por infracción de la garantía del juez indiferente, aparece más eficaz su alegación como un motivo absoluto de nulidad del artículo 374 del Código Procesal Penal, precisamente, por constituir una de esas causales que liberan al recurrente de la carga de probar el perjuicio y la trascendencia del vicio.

\section{Procedimientos de amparo de la garantía de imparcialidad del Tribunal de Juicio Oral en lo Penal}

Probablemente una de las principales dificultades advertidas en el debate judicial sobre la imparcialidad del Tribunal de Juicio Oral en lo Penal se refiere al procedimiento aplicable. A nuestro juicio, la confusión entre los procedimientos cautelares o destinados a prevenir la infracción de la garantía con aquéllos destinados a la reparación, represión o invalidación de la decisión parcial, sólo han contribuido a crear un creciente desorden argumentativo.

A efectos de sistematizar y proponer un camino racional de discusión en esta materia, consideramos que el procedimiento destinado a precaver la afectación de esta garantía debe relacionarse con aquello que el profesor J. Clariá Olmedo denomina causales preexistentes de parcialidad del juzgador ${ }^{91}$. En nuestra legislación aquéllas se reducen a los motivos de implicancia y recusación, reconocidos en los artículos 195 y 196 del Código Orgánico de Tribunales, los mismos que, como ya se dijo, coincidiendo con la tesis de Remberto Valdés Hueche, no satisfacen las exigencias y extensión de la garantía de imparcialidad del tribunal como ha sido entendida por el derecho comparado e internacional ${ }^{92}$.

${ }^{91}$ Clariá Olmedo, Jorge, Derecho Procesal Penal, Tomo I, Ed. Rubinzal-Culzoni, Buenos Aires, 2001, p. 299.

92 Las causales legales y preexistentes de inhabilitación del juzgador necesariamente deben alegarse en las oportunidades previstas en el artículo 76 del Código Procesal Penal (nunca después de iniciado el juicio oral), entre otras razones, porque la causal de nulidad del artículo 373 a) del mismo texto legal exige cumplir con la exigencia de preparación previa del recurso de conformidad con lo dispuesto en el artículo 377 del Código Procesal Penal, cuestión que quedaría incumplida si no se alegó oportunamente la respectiva implicancia o recusación del tribunal. Si el motivo de falta de imparcialidad, en cambio, no aparece descrito en las causales legales de inhabilitación del juez, entonces creemos que es posible invocar sin necesidad de preparación previa del recurso, el motivo genérico de nulidad del juicio oral y la sentencia establecido en el artículo 373 a) del Código Procesal Penal. 
En la causa Rol 4181-09, la Excma. Corte Suprema en resolución de 19 de noviembre de 2009 sostuvo que a partir de los pronunciamientos de la Corte Interamericana de Derechos Humanos y, tal como lo comenta Jauchen, se consagra el principio conceptual de que los motivos de parcialidad y en consecuencia de apartamiento del juez no se limitan a las taxativas causales de recusación enumeradas en los digestos procesales, sino que también existe una variada gama de situaciones imposibles de enumerar pero que, genéricamente, aun cuando no estén expresamente previstas, configuran objetivamente motivos de apartamiento por colocar al juez o tribunal en duda sobre su imparcialidad.

De lege ferenda, entonces, ese catálogo debiera ampliarse y reconocer nuevas circunstancias de afectación objetiva de la garantía con el propósito de incrementar la confianza de los justiciables en la honestidad y recta administración de justicia, de modo de asegurar que los temores fundados de juzgamientos interesados puedan abrirse a un verdadero debate previo al inicio del juicio, porque la verdad es que hoy, con las normas vigentes, esa discusión es más aparente que real. Así por ejemplo, un incidente sobre inhabilitación de uno de los jueces del Tribunal Oral en lo Penal que anticipa opinión por la prensa antes del juicio con toda seguridad será rechazado in limine, desde que no hay una causal de implicancia o recusación que aborde esta circunstancia y permita una recepción favorable antes del acto procesal de juzgamiento.

En cambio, los casos de parcialidad preexistente, ajenos al contenido de las causales de implicancia y recusación enumeradas en el Código Orgánico de Tribunales, como también aquéllas de carácter sobreviniente o recién conocidos durante la tramitación del juicio oral, en expresión de Clariá Olmedo ${ }^{93}$, deberán ser reparadas a través del ejercicio del recurso de nulidad. Ese es el medio ordinario ${ }^{94}$ de impugnación de la sentencia definitiva pronunciada por el Tribunal de Juicio Oral en lo Penal y que, de prosperar, permite invalidar el juzgamiento y la decisión adoptada con infracción de garantías fundamentales. Lo anterior, sin perjuicio de la facultad reconocida a todos los jueces para inhabilitarse de oficio en cualquier etapa del procedimiento, incluso luego de iniciada la audiencia para conocer y resolver la acusación fiscal, de conformidad con el artículo 200 del Código Orgánico de Tribunales en relación con el inciso tercero del artículo 76 del Código Procesal Penal.

Sobre el particular, la Excma. Corte Suprema ha dicho que resulta imperativo aceptar que, si bien tradicionalmente la imparcialidad del tribunal se ha tutelado por medio de las causales de implicancia y recusación, que pueden ser promovidas en forma incidental por la parte interesada o bien de oficio por el propio juzgador, una reclamación posterior a una decisión de un órgano jurisdiccional, relativa a la ausencia de este derecho esencial del debido proceso, no puede limitarse, a la luz de la denominada imparcialidad

93 Clariá Olmedo, Jorge, Derecho Procesal Penal, ob. cit. loc. cit.

${ }^{94}$ Esta expresión está tomada del habla como sinónimo de común, regular y de uso habitual. No ha sido empleada en el sentido jurídico procesal, que entiende a los recursos ordinarios como opuestos a los extraordinarios, de derecho estricto y causales taxativas, desde que genéricamente permiten reparar cualquier clase de errores, sin exigir causas específicas para su admisión y sin que, además, limiten los poderes del tribunal ad quem. Técnicamente hablando, el recurso de nulidad es un recurso extraordinario. 
objetiva, a la rigidez de los motivos legales de inhabilidad, que han de interpretarse en relación a los principios constitucionales informadores del proceso penal, de lo que se desprende que ese tipo de vicios pueden ser reprimidos por la vía del recurso de nulidad e incluso a través del recurso de queja, como quedó establecido en la causa Rol 4181-09 del máximo tribunal del país.

\section{3a. El procedimiento preventivo o cautelar}

De acuerdo a la legislación vigente, las solicitudes de inhabilitación de los jueces del Tribunal de Juicio Oral en lo Penal deberán plantearse, a más tardar, dentro de los tres días siguientes a la notificación de la resolución que fijare fecha para el juicio oral, debiendo resolverse con anterioridad a la respectiva audiencia ${ }^{95}$.

Cuando los hechos que constituyeren la causal de implicancia o recusación, llegaren a conocimiento de la parte con posterioridad al plazo indicado precedentemente pero antes del inicio del juicio, el incidente se deberá promover como la primera cuestión a ser debatida una vez comenzada la audiencia.

Es fácil advertir que el procedimiento de cautela de la garantía de imparcialidad del Tribunal Oral aparece reducido en una doble perspectiva que restringe su contenido material y acota la oportunidad de su reclamo, pues sólo se pueden alegar por esta vía las estrechas causales de inhabilitación de los artículos 195 y 196 del Código Orgánico de Tribunales y no es posible promover su discusión una vez iniciada la audiencia de juicio.

Discrepamos, en consecuencia, de la resolución pronunciada por el Tribunal Oral en lo Penal de Puerto Montt que en la causa RIT 58-2007 sostuvo que la limitación temporal establecida por el Código Procesal Penal para la alegación de la inhabilitación de los jueces, no excluye la posibilidad que los intervinientes puedan promover incidentes con dicho fin durante el juicio oral, precisamente, en aquellos casos en que la causal de inhabilidad se genere o aparezca de manifiesto durante el transcurso de tal audiencia, lo que en tal caso debe hacerse respetando la normativa general sobre incidentes, porque impedirlo resultaría incompatible con el respeto de los derechos y garantías procesales referidas al debido proceso penal.

En ese caso, sin embargo, el Tribunal Oral en lo Penal de Puerto Montt rechazó el incidente de inhabilidad promovido por la defensa en la causa RIT 58-2007, fundado en el hecho de no haberse alegado de inmediato y en cuanto la defensa tomó conocimiento de la causal de recusación, reservando su alegación para el alegato de clausura del juicio ${ }^{96}$.

95 Artículo 76 del Código Procesal Penal.

${ }^{96}$ A nuestro juicio el Tribunal Oral en lo Penal de Puerto Montt en este caso concreto de la causa RIT 58-2007 ignoró y confundió los procedimientos cautelares y represivos de infracción a la garantía del juez imparcial, además de confundir las sesiones del juicio oral con la audiencia de juicio oral, razón por la cual estimó que hubo preclusión del derecho al no haberse alegado la inhabilitación del juez inmediatamente de conocida. 
A nuestro juicio esta resolución es errada, porque el procedimiento cautelar de la garantía de imparcialidad del tribunal expira una vez iniciada la audiencia de juicio como expresamente lo prescribe la ley procesal penal ${ }^{97}$. Consideramos errado el criterio sustentado por el Tribunal Oral en lo Penal de Puerto Montt cuando ha sostenido que impedir su alegación durante el juicio no infringe el debido proceso, desde que ese razonamiento ignora que la preclusión de la oportunidad para alegar las causales de implicancia y recusación antes del juzgamiento, es sin perjuicio del derecho de las partes a ejercer con posterioridad al pronunciamiento de la sentencia el procedimiento represivo o reparatorio de la infracción de la garantía de imparcialidad del tribunal mediante la interposición del respectivo recurso de nulidad.

\section{3ai. El tribunal competente}

En cuanto a la competencia, el incidente de cautela de la imparcialidad del juez debe ser resuelto por el Tribunal Oral en lo Penal, sea que se solicite la implicancia o recusación de alguno de sus jueces. Así se establece en el artículo 76 del Código Procesal Penal y sobre esta materia la Excma. Corte Suprema ha sido categórica cuando en la causa Rol No 2426-2007 ha dicho en su considerando décimo quinto que el tribunal llamado a decidir acerca de las solicitudes de inhabilitación es aquel a quien incumbe conocer del litigio.

Hay controversia, sin embargo, sobre el modo como se debe resolver esta materia. Si bien en el denominado caso Piccardo, la defensa de los condenados cuestionó que el incidente de inhabilitación del juez presidente de la sala del Tribunal Oral en lo Penal fuera resuelto sin su exclusión y permitiendo que su voto integrara el rechazo de la solicitud, lo cierto es que sobre este punto no se pronunció la Excma. Corte Suprema al desestimar el recurso de nulidad que reclamaba la infracción a la garantía del juez imparcial.

Se debe tener presente que el artículo 282 del Código Procesal Penal establece que el juicio oral se desarrollará en forma continua y podrá prolongarse en sesiones sucesivas hasta su conclusión, razón por la cual creemos que en general los derechos susceptibles de reclamarse durante la audiencia de juicio oral no precluyen, sino hasta su término, tal como lo prescribe el artículo 161 del Código Procesal Penal que regula la oportunidad para solicitar la nulidad procesal de una actuación judicial defectuosa.

Sin embargo, de acuerdo al artículo 290 del Código Procesal Penal los incidentes promovidos en el transcurso de la audiencia de juicio oral sí deberán ser resueltos inmediatamente por el tribunal y las decisiones que recayeren sobre estos incidentes no serán susceptibles de recurso alguno.

97 Artículo 76 Código Procesal Penal: Las solicitudes de inhabilitación de los jueces del tribunal de juicio oral deberán plantearse, a más tardar, dentro de los tres días siguientes a la notificación de la resolución que fijare fecha para el juicio oral, y se resolverán con anterioridad al inicio de la respectiva audiencia.

Cuando los hechos que constituyeren la causal de implicancia o recusación llegaren a conocimiento de la parte con posterioridad al vencimiento del plazo previsto en el inciso anterior y antes del juicio oral, el incidente respectivo deberá ser promovido al iniciarse la audiencia del juicio oral. 
Postulamos, por último, que una interpretación sistemática de las normas vigentes, específicamente los artículos 202 y siguientes del Código Orgánico de Tribunales ${ }^{98}$, amén de las garantías de un debido proceso penal, imponen en virtud de la dimensión objetiva de la garantía de imparcialidad que el juez cuya inhabilitación ha sido solicitada por las partes, sea excluido de la deliberación y decisión del respectivo incidente, tal como lo resolvió el Tribunal Oral en lo Penal de Puerto Montt en la caso PaillaleveMancilla, oportunidad en la que se formó una sala especial a fin de evitar que los jueces cuya implicancia fue solicitada por la defensa concurrieran a la resolución de un asunto en el que aparecían directamente interesados, resguardando así el principio de la buena fe procesal y de las apariencias de indiferencia judicial frente a las pretensiones de los intervinientes.

3aii.Inhabilitación de oficio de uno de los jueces del tribunal de juicio oral en lo penal

Si bien hemos postulado que el control preventivo de afectación de la garantía de imparcialidad del juez del Tribunal Oral en lo Penal precluye si no fue ejercido por las partes antes del inicio del juicio oral, tal como lo establece el artículo 76 del Código Procesal Penal, creemos, sin embargo, que nada obsta a ejercer una suerte de procedimiento informal o amistoso posterior, no vinculante para el tribunal ${ }^{99}$, cuando la causal de implicancia o recusación fue conocida luego de la apertura de la audiencia de juzgamiento y antes de la deliberación privada de los jueces.

Utilizaremos la expresión "procedimiento informal" 100 para referirnos a la facultad de las partes de informar a los jueces durante el desarrollo de la audiencia de juicio oral, de aquellos hechos que han llegado a su conocimiento una vez extinguida la oportunidad de efectuar el control preventivo de imparcialidad y que podrían configurar una causal de inhabilitación, ello con el sólo propósito de que el juez de oficio decida si se margina o no de la audiencia de juzgamiento, en los términos previstos en el inciso

98 Ninguna de las normas del Código Orgánico de Tribunales autoriza que tratándose de órganos colegiados las solicitudes de implicancia y recusación sea resuelta con la intervención del juez cuya inhabilitación se solicita.

99 Precisamente por no tratarse de una causal vinculante para el tribunal es que la calificamos de amistosa, razón en virtud de la cual estimamos que puede solicitarse después de iniciado el juicio oral.

${ }^{100}$ La expresión "procedimiento informal” fue tomada de la Memoria de Prueba para optar al Grado de Licenciado en Ciencias Jurídicas y Sociales de la Universidad de Chile, escrita por Álvaro Hernández Duco, bajo el título "La imparcialidad de los jueces", Santiago, 1990, p. 211. Esta denominación es ilustrativa de lo que proponemos en materia procesal penal para promover la inhabilitación de oficio del juez con posterioridad al inicio de la audiencia de juicio oral, porque así llama Hernández Duco al procedimiento que en materia civil permite ejercer la recusación amistosa o recusación graciosa del artículo Art. 124 del Código de Procedimiento Civil y que reza: antes de pedir la recusación de un juez al tribunal que deba conocer del incidente, podrá el recusante ocurrir al mismo recusado, si funciona solo, o al tribunal de que forme parte, exponiéndole la causa en que la recusación se funda y pidiéndole la declare sin más trámite. 
tercero del artículo 76 del Código Procesal Penal ${ }^{101}$ en relación con el 199 y 200 del Código Orgánico de Tribunales.

Es lo que ocurrió en la causa RIT 56-2008 del Tribunal Oral en lo Penal de Puerto Montt. Se sometió a conocimiento de esa instancia una acusación fiscal por hechos que el Ministerio Público calificó como constitutivos de un porte ilegal de arma de fuego ocurrido en la comuna de Hualaihué, Provincia de Palena.

Mientras la defensa del acusado incorporaba prueba documental, mediante la lectura de una resolución de la Iltma. Corte de Apelaciones de Puerto Montt que había rechazado una apelación del Ministerio Público en contra de la denegatoria de prisión preventiva del acusado, se advirtió, por la fiscal del Ministerio Público, que en ese pronunciamiento había intervenido como ministra suplente del Tribunal de Alzada precisamente una de las juezas que integraba la sala del Tribunal Oral que estaba conociendo del caso, quien, por supuesto, al tomar noticia de ese hecho se inhabilitó de oficio. El tribunal continuó sus funciones sin el juez inhabilitado tal como lo señala el inciso cuarto del artículo 76 del Código Procesal Penal.

\section{3b. Procedimiento represivo o reparatorio de la infracción a la garantía de imparcialidad}

De la revisión de casos expuestos en este trabajo, es fácil advertir los desincentivos normativos y la resistencia jurisprudencial a las solicitudes de inhabilitación previa al juzgamiento de los jueces del Tribunal Oral en lo Penal. En los casos en que las causales de implicancia y recusación han producido efectos precautorios sobre la garantía en cuestión, más que a una actuación de las partes se ha debido a las actitudes personales de los jueces que de oficio se han marginado de juzgamientos que comprometen su imparcialidad, en virtud de lo dispuesto en los artículos 199 y 200 del Código Orgánico de Tribunales ${ }^{102}$.

En cuanto al recurso de nulidad, entendido como el procedimiento reparatorio o represivo natural frente a la infracción de la garantía de imparcialidad del tribunal, parece necesario plantear un par de consideraciones.

Primero, es ostensible que los motivos absolutos de nulidad del artículo 374 del Código Procesal Penal, que liberan al recurrente de la carga de acreditar la sustancialidad

101 Artículo 76 inciso tercero del Código Procesal Penal: Con posterioridad al inicio de la audiencia de juicio oral, no podrán deducirse incidentes relativos a la inhabilitación de los jueces que integran el tribunal. Con todo, si cualquiera de los jueces advirtiere un hecho nuevo constitutivo de causal de inhabilidad, el tribunal podrá declararla de oficio.

102 Art. 199 del COT: Los jueces que se consideren comprendidos en alguna de las causas legales de implicancia o recusación, deberán tan pronto como tengan noticia de ello, hacerlo constar en el proceso, declarándose inhabilitados para continuar funcionando, o pidiendo se haga esta declaración por el tribunal de que formen parte. Art. 200 del COT: La implicancia de los jueces puede y debe ser declarada de oficio o a petición de parte. 
y trascendencia de la infracción ${ }^{103}$, ofrecen, al igual que el procedimiento cautelar ya analizado, un sendero estrecho y de difícil tránsito en procura de la reparación.

Desde luego, el contenido de la letra a) de la norma que consagra los motivos absolutos de nulidad, aparece acotado a los casos en que la sentencia se dictó con la concurrencia de un juez de tribunal oral en lo penal legalmente implicado o cuya recusación estuviere pendiente o hubiere sido declarada por tribunal competente, situación casi de laboratorio y que exige en el juzgador una contumacia incompatible con la rectitud exigida por el servicio jurisdiccional, todo lo cual torna más aparente que real su utilidad práctica.

Por lo tanto y tal como ha ocurrido en los casos en que la Excma. Corte Suprema ha resuelto la invalidación de sentencias y juicios realizados con infracción a la garantía del juez imparcial, el derrotero seguido por los defensores ha sido la causal genérica del artículo 373 a) del Código Procesal Penal que permite ampliar su contenido de conformidad con los tratados internacionales sobre derechos humanos, desde que esa norma expresamente así lo reconoce.

Es necesario, entonces, pesquisar el contenido material de la infracción a la garantía de imparcialidad que, por supuesto, excede el catálogo cerrado de causales de implicancia y recusación del Código Orgánico de Tribunales, desde que, por ejemplo, la Excma. Corte Suprema ya en reiterada jurisprudencia ha resuelto, por ejemplo, que las actuaciones indagatorias de los jueces lesionan la necesaria pasividad del juzgador a efectos de garantizar el contradictorio de partes, como también el procedimiento legítimo para generar la información necesaria para decidir con rectitud e imparcialidad un asunto de relevancia penal.

Este procedimiento, por lo menos, permite discutir represivamente circunstancias objetivas de afectación de la garantía de imparcialidad, como, por ejemplo, los juicios emitidos por el juez a través de los medios de comunicación u otras circunstancias que razonablemente produzcan en los justiciables desconfianza objetiva de enfrentar un juzgamiento interesado, siempre que el recurrente cumpla con las requisitos que exigen, entre otros, reclamar oportunamente del vicio o defecto ${ }^{104}$, acreditar el carácter sustancial de la infracción ${ }^{105}$ y demostrar que tuvo influencia en lo dispositivo del fallo ${ }^{106}$.

Si bien por esta vía y hasta donde se conoce, no hay pronunciamientos de la Excma. Corte Suprema que hayan invalidado juicios y sentencia pronunciadas por Tribunales

103 Julián López Masle sostiene que los motivos absolutos de nulidad constituyen causales objetivas de nulidad procesal en que no cabe entrar a discutir si la infracción es sustancial o no y si influye o no en lo dispositivo del fallo. A su vez para Núñez los motivos absolutos de nulidad se denominan así porque importan necesariamente perjuicio para el interviniente, y un vicio sustancial, desde el momento en que constituyen una infracción manifiesta a garantías o derechos fundamentales, cita de Cortez Matcovich, Gonzalo., El recurso de nulidad. Doctrina y Jurisprudencia, Editorial LexisNexis, primera edición, Santiago, 2006, p. 179.

104 Artículo 377 del Código Procesal Penal. Preparación del recurso. Si la infracción invocada como motivo del recurso se refiere a una ley que regulare el procedimiento, el recurso sólo será admisible cuando quien lo entablare hubiere reclamado oportunamente del vicio o defecto.

105 Exigencia impuesta por el artículo 373 a) del Código Procesal Penal

${ }^{106}$ El artículo 375 del Código Procesal Penal establece que no causan nulidad los errores de la sentencia recurrida que no influyeren en su parte dispositiva. 
cuestionados por sospechas serias de parcialidad, la jurisprudencia dominante al menos ya ha proscrito por esta vía reparatoria las actuaciones judiciales positivas que infringen la garantía de imparcialidad del tribunal, como cuando los jueces introducen a las audiencias de juzgamiento información de relevancia penal que desequilibra el debate de partes, en perjuicio de una de ellas o generan prueba de cargo. Nada impide que en un futuro próximo también se repriman y se dejen sin efectos las sentencias pronunciadas por tribunales integrados por jueces sobre quienes pesan apariencias fundadas de prejuicio, tal como lo prescriben los tratados internacionales sobre derechos humanos, expresamente reconocidos en nuestra legislación como un límite al ejercicio de la soberanía y una fuente de derecho directamente aplicable por quienes ejercen la jurisdicción en el ámbito penal.

Dejar de revisar este aspecto de la garantía de la imparcialidad y del debido proceso y peor aún, sostener su irrelevancia, es un peligro no sólo para los acusados, sino también para el resto de la población. A menos que, aquellos que abogan por la restricción del derecho al juez indiferente, deseen encontrarse algún día padeciendo una justicia que dormita bajo sus arbitrariedades.

En este sentido, no cabe duda que la justicia tiene el deber de interrogarse siempre sobre sí misma, al igual como una sociedad, que tan sólo puede vivir de la reflexión y de la acción que ejerce sobre sí misma y sobre sus instituciones”107.

\section{BIBLIOGRAFÍA}

Bordalí Salamanca, Andrés, "El derecho fundamental a un tribunal independiente e imparcial en el ordenamiento jurídico chileno", en Revista de Derecho de la Pontificia Universidad Católica de Valparaíso, $2^{\circ}$ Semestre de 2009.

Clariá Olmedo, Jorge, Derecho Procesal Penal, Tomo I, Ed. Rubinzal-Culzoni, Buenos Aires, 2001.

Colombo Campbell, Juan, Los Actos Procesales, Tomo II, Editorial Jurídica de Chile, Santiago, 1997.

Contesse Singh, Jorge, "Implicancias y recusaciones: el caso del tribunal constitucional. Informe en derecho sobre la inhabilidad constitucional para conocer de un caso en el que se ha vertido opinión pública con anterioridad", en Ius et Praxis, año 13, No 2 , Universidad de Talca, Chile.

Cortez Matcovich, Gonzalo, El recurso de nulidad. Doctrina y Jurisprudencia, Editorial LexisNexis, primera edición, Santiago, 2006.

Díaz García, Luis Iván, "La facultad del tribunal oral en lo penal de aclarar dichos", en Universidad Católica de Temuco, Chile. Seminario Reforma Procesal Penal, Santiago de Chile: Ed. ConoSur, 2001.

Evans de la Cuadra, Enrique, Los Derechos Constitucionales, Tomo II, Editorial Jurídica de Chile, tercera edición, Santiago, 2004.

${ }^{107}$ Foucault, Michel, Vous etes dangereux, Liberation, 10 de junio de 1983, citado por Eribon, Didier., Michel Foucault, Ed. Anagrama, Barcelona, primera edición en compactos, 2004, p. 331. 
Fernández González, Miguel Ángel, La Nueva Justicia Penal frente a la Constitución, Editorial LexisNexis, primera edición, Santiago de Chile, 2006.

Ferrajoli, Luigi, Derecho y razón, Editorial Trotta, Madrid, octava edición, 2006.

Foucault, Michel, Un diálogo sobre el poder y otras conversaciones, Alianza Editorial, Tercera Reimpresión, Madrid, 2007.

Foucault, Michel, Vous etes dangereux, Liberation, 10 de junio de 1983, citado por Eribon, Didier, Michel Foucault, Ed. Anagrama, Barcelona, primera edición en compactos, 2004.

González Casso, Joaquín, Sobre el derecho al juez imparcial, Editorial Dykinson, Madrid, 2004.

Hernández Duco, Álvaro, La Imparcialidad de los Jueces, Memoria de Prueba para optar al grado de Licenciado en Ciencias Jurídicas y Sociales, Facultad de Derecho de la Universidad de Chile, Santiago, 1990.

Maier, Julio, Derecho Procesal Penal, Fundamentos, Editores del Puerto, $2^{\mathrm{a}}$ edición, Buenos Aires, 2002.

Manual de Derecho Internacional de los Derechos Humanos para Defensores Penales Públicos, Ed. Centro de Documentación de la Defensoría Penal Pública, Santiago, diciembre de 2003.

Meroi, Andrea, "Iura novit curia y decisión imparcial”, en Ius et Praxis, año 13, No 2, Universidad de Talca, Chile.

Montero Aroca, Juan, Sobre la imparcialidad del juez y la incompatibilidad de funciones procesales, Editorial Tirant Lo Blanch, Valencia, 1999.

Quinzio F, Jorge Mario, Tratado de Derecho Constitucional, Tomo II, Editorial LexisNexis, primera edición, Santiago de Chile, 2004.

Rodríguez Ramos, Luis, Justicia Penal. Comentarios de sentencias del tribunal constitucional y del tribunal supremo, Colección Iure, dirigida por Jacobo López Barja de Quiroga, Ediciones Akal, Madrid, 1990.

Saavedra Rojas, Edgar, Constitución, Derechos Humanos y Proceso Penal, Ediciones Jurídicas Gustavo Ibáñez C, Santafé de Bogotá, Colombia, 1995.

VAldés Hueche, Remberto, "El proceso. La imparcialidad. Sistema inquisitivo y acusatorio. La concepción unitaria del proceso. La constitución política y los tratados de derechos humanos”, en Revista del Consejo de Defensa del Estado, Chile, No 12, diciembre, 2004.

Valenzuela Cori, Rodrigo, Conflicto y Humanidades. Un Ensayos sobre Argumentación Jurídica, Editorial Jurídica de Chile, Santiago, primera edición, 2004. 